Brit. J. soc. Med. (194̀8), 2, 77-105.

\title{
AMERICAN MEDICAL SERVICES
}

\author{
BY \\ THOMAS McKEOWN \\ From the Department of Social Medicine, University of Birmingham
}

\section{SERVICES PROVIDED BY GOVERNMENT AUTHORITIES}

\section{INTRODUCTION}

In the United States, government responsibility for health and related services is divided between Federal, State, and local agencies, and an intelligible account of their activities requires a brief description of the source and extent of their respective authority.

There is no specific reference to health in the American Constitution, and such powers as the Federal Government possesses are based on commerce, general welfare, and taxation clauses. State authority is derived from the police power of the States, and from an amendment of the Constitution which reads: "the powers not granted to the United States by the Constitution, nor prohibited to it by the States are reserved to the States respectively or to the people" (Mustard, 1945a). The organization of local government is not the same in all States. In some the administrative unit is the county, and in others the township; the scope of both county and town administrations is determined by State legislation. In some areas local units are grouped to form health districts which provide a more satisfactory basis for health administration. In such cases local activities are closely associated with State administration, and are sometimes directly supervised by the State health officer. Most cities have a charter under which they enjoy a considerable degree of autonomy, and their health services are usually independent administratively of those of the State.

The extent of the authority of Federal, State, and local governments is constantly in dispute, and the organization of medicine is caught up in the wider controversy. Some Americans pin their faith on an exact interpretation of the Constitution, which suffers unfortunately, like most ancient guides to modern conduct, from the serious disadvantage of being inadequately documented. One may reasonably doubt whether, had anything retevant to modern medical organization been contained in that document, it would have been any better for having been said a hundred and sixty years ago.

In recent years there has been a fairly rapid encroachment of Federal powers in the fields of health, education, and social security, once considered to be mainly the concern of State and local authorities. In part this has been achieved by a direct extension of Federal responsibility for specific services. It has also resulted from the use of Federal funds as grants-in-aid to the States, a device which leaves to the States immediate administrative responsibility, but extends the influence of the central government through what is politically a less provocative alternative to direct action.

The account which follows is concerned with the organization of health services, and in particular, and to the extent that it can be considered separately, with the organization of curative services. It seems desirable, however, to make first a brief statement on the related services for education and social security.

\section{Education and Social Security}

Fig. 1 shows that Federal expenditure on education increased from 2 per cent. of the total in 1935-36 to 10 per cent. in 1943-44. This service is still essentially administered and paid for by State and local authorities; the Federal contribution is in research and advisory service, and through grantsin-aid.

Federal expenditure on social security is relatively much greater, but the administration is complex and the Federal contribution varies from one service to another (Table I). Of funds spent on public assistance to the aged, dependent children, and the blind, slightly more than half are derived from Federal sources, and are distributed mainly as grants-in-aid to the States. Other forms of public assistance are limited in scope, and are financed by the States. Contributory old age and survivors insurance is controlled exclusively by the central government. Unemployment benefits (collected by a tax on employers on wages up to $\$ 3,000$ per year) are paid from State trust funds, and the costs of administration, from Federal grants-in-aid. Table I gives details of other special classes of security benefit in which the Federal and State governments participate.

The total expenditure on all of these services is 


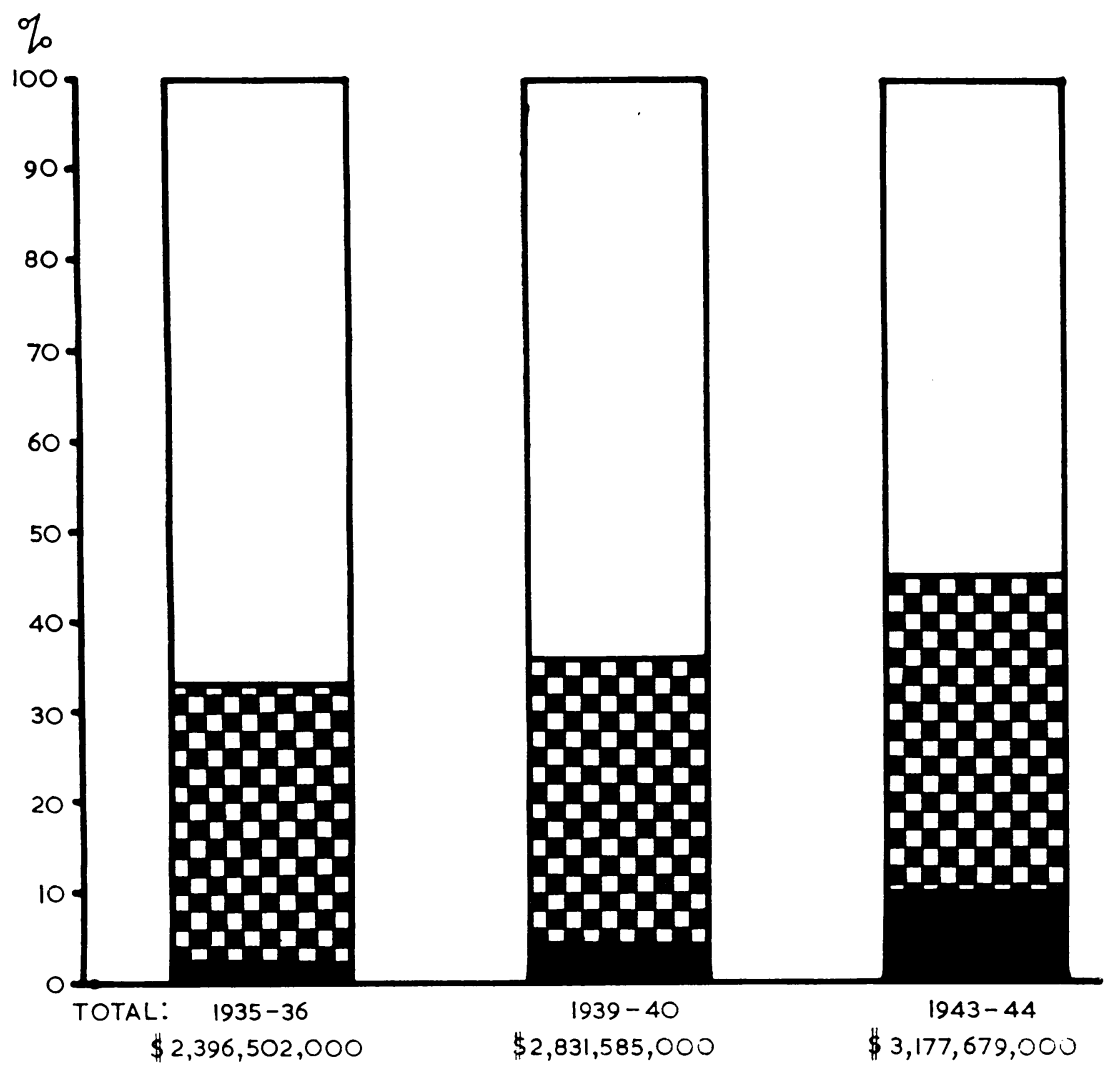

constantly changing, as are the relative contributtions of the Federal, Statc, and local agencies. Their respective roles were altered profoundly by the circumstances which led to the Social Security Act of 1935, and it is likely that any significant changes in social and economic conditions will continue to be reflected in further modifications of the administrative machinery.

\section{HeAlth}

It will be convenient to consider first the overall expenditure on health, before directing attention in more detail to the services provided by Federal, State, and local governments. Responsibility for finance and administration is again divided between the three levels of government, and Fig. 2 compares the annual expenditure for the five years 1940-41 to 1944-45. In this time total expenditure increased by 58.5 per cent.; the Federal contribution increased by 167 per cent. (a) Federal Services.-A detailed description $\stackrel{0}{0.0}$ the complex machinery of Federal administration would greatly extend the scope of this discussion and it will suffice to state summarily that while many government departments are concerned in some degree, most services related to health are the responsibility of the Federal Security Agency.or It includes the Public Health Service, the Office ofo Education, the Social Security Board (now thro Social Security Administration), the Food and Drug Administration, the Office of Vocational Rehabilitas tion, and since 1946 most of the Children's Bureate as well as what had previously been the vitab statistics section of the Census Bureau. In spite of the scope and importance of its numerous functions, the Federal Security Agency is not $\vec{\Phi}$

* Of many agencies not included in the Federal Security Agenc the following are particularly important: The Bureau of Huma Nutrition and Home Economics in the Department of Agriculture the Office of Indian Affairs and the Bureau of Mines in the Depart ment of the Interior; the Federal Public Housing Authority; tho ment of the Interior; the Federal Public Housing Authority; the
Veterans Administration. 


\section{PUBLIC EXPENDITURE for HEALTH and MEDICAL CARE SERVICES}

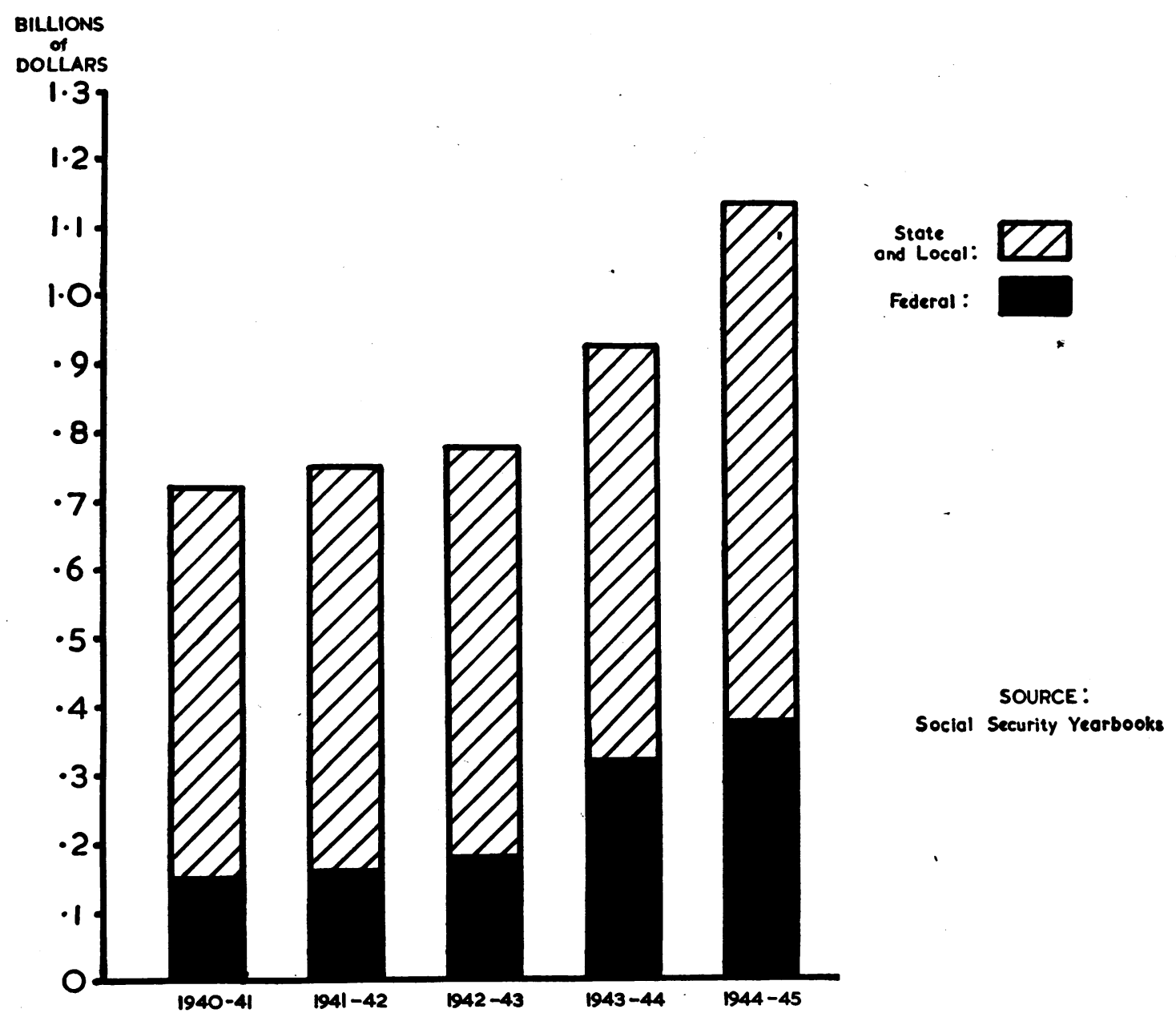

FIG. 2.

cabinet department (that is, its head is not a member of the cabinet). A plan to make it such has been considered at intervals for many years, and renewed sponsorship of the proposal by the President in 1946 resulted in two bills now under discussion (the Fulbright-Taft Bill, S.140; and the Aitken Bill, S.712) which provide for the establishment of a cabinet department of Health, Education, and Security. The only serious objections which have been raised, those of the medical profession, are grounded on a reluctance to accept an association of health with other services, with the attendant danger of its subordination to them. Implementation of the proposal would no doubt augment the authority of the department, but would not necessarily alter substantially the nature of the work already undertaken by the Federal Security Agency. The activities of the agency which are concerned directly with health are concentrated in the United States Public Health Service.

(i) Assistance to the States.-The United States Public Health Service has assisted the development of State health services in various ways which avoid imposition on local administrations of the burden 


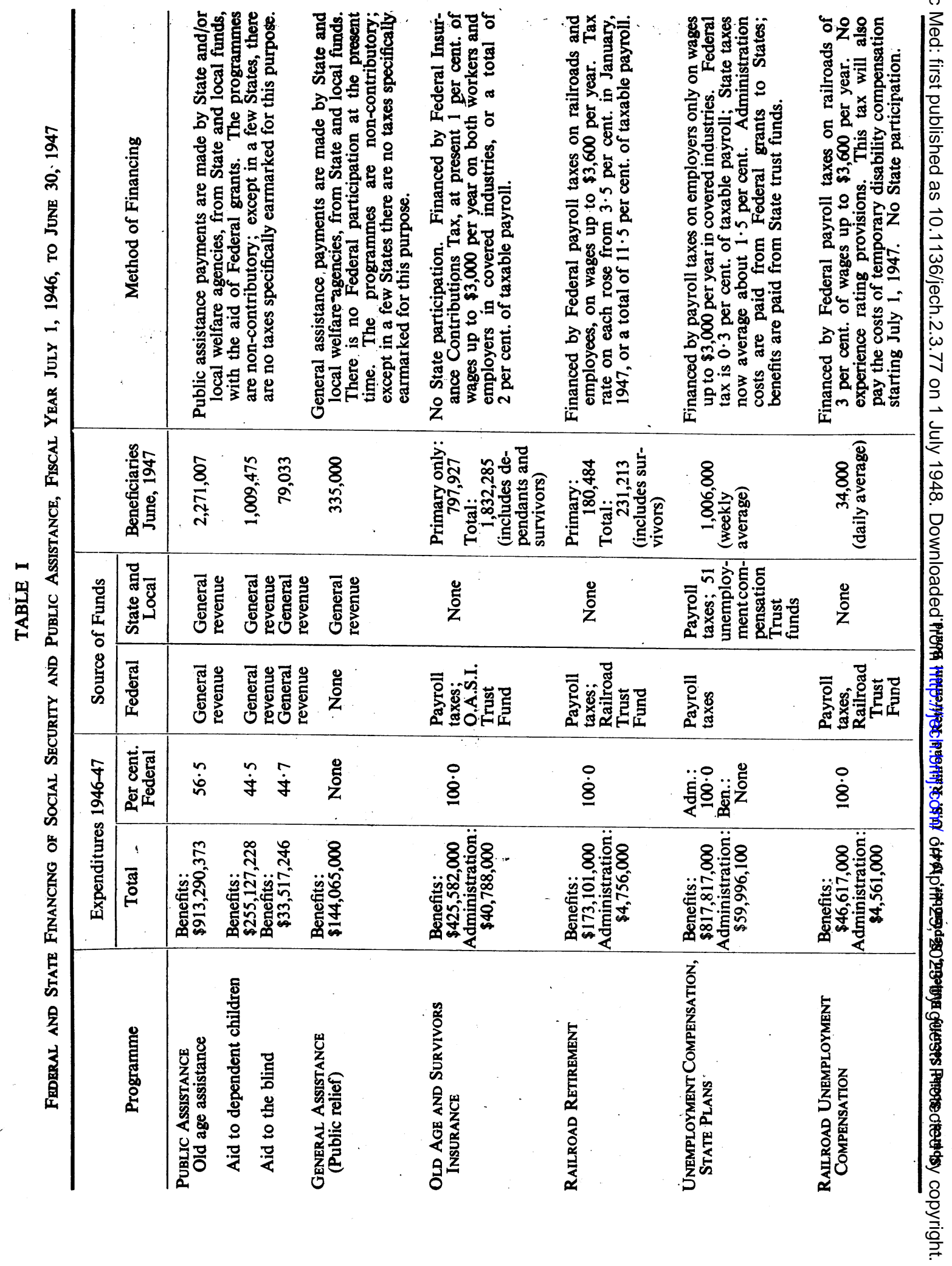


TABLE II

Annual Expenditure on Health by all State AGENCIES*

\begin{tabular}{|c|c|c|c|c|}
\hline & \multicolumn{2}{|c|}{$\begin{array}{c}\text { Expenditure } \\
\text { (dollars) }\end{array}$} & \multicolumn{2}{|c|}{$\begin{array}{ll}\text { Total } & 285,715,800 \\
\text { Per capita } & 1 \cdot 90\end{array}$} \\
\hline & $\begin{array}{l}\text { urce } \\
\text { f total) }\end{array}$ & & $\begin{array}{l}\text { Expenditure } \\
\text { (\% of total) }\end{array}$ & \\
\hline $\begin{array}{l}\text { State } \\
\text { Local } \\
\\
\text { U.S. P } \\
\text { Ser } \\
\text { U.S. P } \\
\text { Ser } \\
\text { fun } \\
\text { U.S. C } \\
\text { Bu } \\
\text { Other }\end{array}$ & 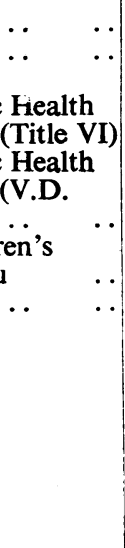 & $\begin{array}{r}81 \cdot 4 \\
3.9 \\
3 \cdot 2 \\
\\
1.0 \\
2.5 \\
8 \cdot 0\end{array}$ & 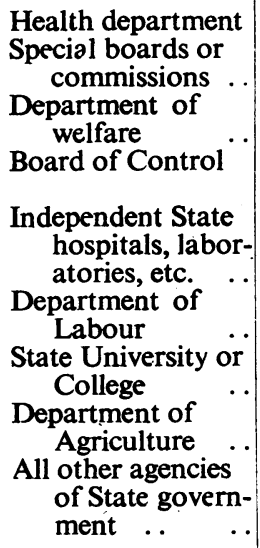 & $\begin{array}{l}5 \cdot 4 \\
3 \cdot 2 \\
3 \cdot 2 \\
2 \cdot 3 \\
5 \cdot 1\end{array}$ \\
\hline Total & $\cdots$ & 100 & Total & 100 \\
\hline
\end{tabular}

* Source: Mountin, Joseph W., and Flook, Evelyn. " Distribution of Health Services in the Structure of State Government: The Composite Pattern of State Health Services." Public Health Reports, 56, 1676 (1941). Modified.

of a remote central control. These methods include the seconding of trained personnel, research on local problems, education of local staff, and perhaps most important, the distribution of monetary grants-in-aid. The last has been at once the most useful and the most controversial device, since by defining the conditions on which grants are made, the Federal Government has been able to insist on local financial participation (by requiring matched grants) and to determine in some measure the direction of local development.

To the extent that this assistance has been used to promote a conventional public health programme, progress, if not rapid, has been fairly continuous. The infectious diseases, venereal disease, tuberculosis, and some aspects of hospitals, dentistry, and industrial hygiene, are acceptable to many people as government responsibilities, with which the assistance of central to State and local authorities is not resented. But when the issue of Federal as opposed to State control impinges on the issue of government as opposed to non-government, any suggestion of Federal encroachment on local activity is resisted, even when it takes the form of assistance. It is in the organization of curative services that opposition is most evident, and the problem is discussed more fully in (2).

(ii) Research and Education.-The Federal Government, through its principal health agency, the United States Public Health Service, has contributed vigorously to education and research. It maintains a large research unit, the National Institute of Health, which includes in its interests investigations in cancer, infectious diseases, physiology, biologics control, chemistry, zoology, and industrial hygiene research.

(iii) Medical Services.-Medical services are provided directly by the central government to the following groups: seamen, inmates of Federal prisons, the indigent, the Indians, disabled veterans, compensation cases of Federal employees, and to members of the armed forces (Stern, 1946a). In recent years these services have been considerably expanded, a fact which is discussed more fully under (2). Other services directly provided include hospitals for drug addicts and for certain cases of mental illness, and medical inspection related to quarantine and immigration.

(b) State Services.-At the State, as well as at the Federal level, health services are divided between several departments (Mountin and Flook, 1941). The number of departments concerned is different in different States, as is the organization of the health department. But, with the exceptions of Idaho and Nebraska, all States have to-day either a board of health, or an advisory council or committee (Mustard, 1945b).

TABLE III

Annual Expenditure on Health by State Health DEPARTMENTS*

\begin{tabular}{|c|c|c|c|c|}
\hline \multicolumn{2}{|c|}{$\left.\begin{array}{c}\text { Expenditure } \\
\text { (dollais) }\end{array}\right\}$} & \multicolumn{3}{|c|}{$\begin{array}{ll}\text { Total } & 52,896,200 \\
\text { Per capita } & 0 \cdot 395\end{array}$} \\
\hline $\begin{array}{l}\text { Source } \\
(\% \text { of total) }\end{array}$ & & $\begin{array}{l}\text { Expendi } \\
(\% \text { of } t\end{array}$ & & \\
\hline $\begin{array}{l}\text { State } \\
\text { Local } \\
\text { U.S. Public Health } \\
\text { Service (Title VI) } \\
\text { U.S. Public Health } \\
\text { Service (V.D. } \\
\text { funds) . } \\
\text { U.S. Children's } \\
\text { Bureau (Title V) } \\
\text { Other }\end{array}$ & $\begin{array}{r}63 \cdot 1 \\
1 \cdot 6 \\
17 \cdot 1 \\
\\
5 \cdot 3 \\
10 \cdot 4 \\
2 \cdot 5\end{array}$ & $\begin{array}{l}\text { Central office } \\
\text { services } \\
\text { Field services } \\
\text { Local grants } \\
\text { Hospitals }\end{array}$ & $\begin{array}{l}\ldots \\
\cdots \\
\cdots\end{array}$ & $\begin{array}{l}23 \cdot 3 \\
35 \cdot 2 \\
21 \cdot 3 \\
20 \cdot 2\end{array}$ \\
\hline Total & 100 & Total &. & 100 \\
\hline
\end{tabular}

* Source: Mountin, Joseph W., and Flook, Evelyn. "Distribution of Health Services in the Structure of State Government: State Health Department Organization." Public Health Reports, 58, 568 (1943). Modified. 
Table II gives the total annual expenditure on health by all State agencies as $\$ 285,715,800$ ( $\$ 1.90$ per capita). Of this sum, $81 \cdot 4$ per cent. was derived from State funds, and the remainder from Federal, local, or other sources. Of the total expenditure, $\$ 52,896,200$ (18.5 per cent.) was spent by the State health departments; two-thirds of this sum was provided by State, and one-third by Federal funds (Table III). The proportion of the expenditure paid by the Federal Government is not the same in every State, but is determined by a system of weighting which takes account of the population, wealth, and health problems of each State.

The services which the American Public Health Association (1940a) considers should be supplied by the State health departments are as follows:

1. Study of state health problems and planning for their solution as may be necessary.

2. Co-ordination and technical supervision of local health activities.

3. Financial aid to local health departments as required.

4. Enactment of regulations dealing with sanitation, disease control, and public health, which have the force of law tbroughout the State.

5. Establishment and enforcement of minimum standards of performance of work of health departments, particularly in communities receiving State aid for public health.

6. Maintenance of a central laboratory, and where necessary branch laboratories, for the standard functions of diagnostic, sanitary, and chemical examinations; production or procurement of therapeutic and prophylactic preparations, and their free distribution for public health purposes; establishment of standards for the conduct of diagnostic laboratories throughout the State; labol atory research into the causes and means of control of preyentable diseases.

7. Collection, tabulation, and publication of vital statistics for each important political or health administrative urit of the State and for the State as a whole.

8. Collection and distribution of information concerning preventable diseases throughout the State.

9. Maintenance of safe quality of water supplies and control of the character of the disposal of human waste for all communities of the State.

10. Establishment and enforcement of minimum sanitary standards for milk supplies.

11. Provision for services to aid industry in the study and control of health hazards due to occupation.

12. Prescription of qualifications for certain public health personnel.

13. Formulation of plans in co-operation with other appropriate agencies for the prompt mobilization of services to meet the health needs.
Not all of these services are offered in every State, nor is their quality uniform. It is, moreover, at the local rather than at the State level that most health activities are administered, and the need for State action is inevitably most acute where local services are deficient. Indeed having regard to the difficulties in many local areas discussed below, progress must be slow unless the States make mandatory the provision of services which are at present optional, and themselves take responsibility at least in some areas for work which has traditionally been left to the local authorities.

(c) Local Services. - The American Public Health Association (1940b) has listed the services which should be provided by local health departments as follows: vital statistics; sanitation; control of communicable and preventable disease; laboratory service; protection of health in maternity, infancy, and childhood; and public health education. Not all of these services are available in all parts of the country, and the standards of practice are uneven. According to Mustard (1945c) "from thirty to thirty-five million people have not been provided with the benefits of the not inconsiderable public health knowledge at present available."

A first difficulty in the correction of these deficiencies is the unsatisfactory units of local administration in parts of the country. As already indicated, the unit varies from State to State, and even on the most generous estimate of State initiative it is hard to be optimistic about the rate of progress in a matter which requires separate action from each State. It is not only that certain of the local units are unsatisfactory in population and area for public health administration; many of them are too poor to finance the necessary services.

\section{THE GOVERNMENT AND MEDICAL CARE}

While there are differences of opinion about the respective roles of Federal, State, and local governments in the provision of the public health services already referred to, there is general agreement that they are properly the responsibility of one or other of the government agencies. It is about the relationship of the government to curative services that more serious differences arise, and it will be necessary to discuss briefly the background of this controversy.

In the past, government activity in the curative field has been restricted to the care of such special classes as seamen, the Indians, prison inmates, and the indigent, by the Federal Government, and of such as the tuberculous, the mentally ill, and crippled children by State and local governments. 
For some years it has been suggested that these benefits should be extended to other sections of the population through a Federal service supported either by taxation or by compulsory insurance. This proposal is opposed by those people who think that the service if provided should be controlled by State and not by Federal agencies, and by those who believe that, with the exception of the special classes already referred to, medical care should be the responsibility of the medical profession, and not of either the Federal or State governments. In spite of these views the movement towards extensive Federal participation in curative services has undoubtedly gained force in recent years, and it will be worth mentioning some of the factors which have contributed to it.

(a) Expañsion of Federal Services.-Several of the services traditionally assigned to the central government were expanded rapidly in the war period. Since 1938 the Department of Agriculture has co-operated with State and local agencies to provide medical care for low-income farm workers and their dependants. During the war it became necessary to consider also the needs of migratory farm workers, and a programme of medical care was developed which was no longer restricted to workers ineligible for local medical assistance, and which has become a permanent responsibility of the Department of Agriculture.

In 1943 Congress established an Emergency Maternity and Infant Care Programme, for the dependants of service men in the lower grades of pay. This scheme was operated during the war by the Children's Bureau through State agencies, and provided for the medical care of the mother during and immediately after pregnancy, and of the new-born child.

Easily the most ambitious service undertaken by the government was the medical care of members of the armed forces, and of particular interest is the extended service subsequently developed for war veterans under the Veterans Administration, to-day the largest undertaking of the Federal Government in the field of direct medical service to civilians (Stern, 1946b). The government is required by law to provide complete medical care for veterans whose disabilities are attributable to war service, and hospital care for veterans with conditions unrelated to war service if they are themselves unable to meet the cost. In practice the reservations in respect of eligibility and scope of benefit have not been insisted on, and large numbers of persons are now treated by the Veterans Administration for illnesses totally unconnected with war service.

It is impossible to estimate the effect of this service on future developments. But the fact is that an influential section of the adult population during and since the war has received its medical attention from a co-ordinated service without charge. This experience can hardly fail to influence the attitude of the veteran to legislation which would guarantee not only a continuation of the benefits for himself, but their extension to cover the medical needs of his dependants.

(b) INVESTIGATIONS OF THE Distribution OF Medical CARE.-The movement has had further support from the results of three major investigations which have put beyond dispute a considerable body of information on medical care. The objectives in each case were broadly the same: to determine the incidence of illness in a general population, and to assess the effectiveness of existing services in distributing medical care.

1. Hagerstown morbidity studies, 1921-24. (Sydenstricker, 1926.) Based on enquiries about a population of 7,000 persons visited at intervals of six to eight weeks over a period of twenty-eight months.

2. Survey by the United States Public Health Service and the Committee on the Costs of Medical Care, 1928-31. (Falk, Klem, and Sinai, 1933.)

3. National Health Survey, 1935-36 (1945). Based on enquiries about the health and medical care of two and a half million persons over a period of twelve months preceding a single interview.

Though expensive to carry out,* and unsatisfactory as a method of enquiry for certain of the questions considered, these surveys gave results which were quite consistent on some essentials. The conclusion which concerns us here, and which is supported by all three, is that as judged by the medical attention received by large sections of the population, the existing medical services were seriously deficient. It says much for the investigations that this conclusion is not seriously challenged, however widely opinions differ about the remedy.

\section{Legislation Related to Medical Care}

In November, 1945, the President urged Congress to institute a National Health Programme, which would recognize " the right to adequate medical care and the opportunity to achieve and enjoy good health" and "the right to adequate protection from the economic fears of sickness." $\dagger$ The President believed that such a programme could be implemented without radical changes in the

* It is only right to recognize that the objective of the National Health Survey was to spend, and not to save money.

† English readers are reminded that Congress and not the executive is responsible for the introduction of new legislation. 
organization of medical services, and emphasized five basic problems for consideration:

1. Uneven distribution of doctors and inadequate hospital facilities in many areas.

2. Inadequate Public Health and Maternal and Child Health Services.

3. Need for more extensive provision for research and for medical education.

4. Inability of many people to afford the costs of medical care.

5. Need for compensation of workers for loss of earnings resulting from sickness and disablement.

The President proposed that " Congress adopt a comprehensive and modern health programme for the nation, consisting of five major parts, each of which contributes to all the others ":

1. Construction of hospitals and related facilities through federal grants-in-aid to the States.
2. Expansion of Public Health and Maternal and Child Health Services.

3. The development of a broad federal programme of support for medical education and research.

4. The introduction of prepayment of medical costs through expansion of the existing compulsory social insurance system.

5. Protection against loss of wages from sickness and disability through expansion of the existing compulsory social insurance system.

For some years Congress has had under consideration a number of bills related to various aspects of the medical services. The most controversial is the Wagner-Murray-Dingell Bill, which was modified and reintroduced in 1947 as the National Insurance and Public Health Act of 1947 (S.1320). In the same year an alternative bill was introduced by Taft and others (the National Health Act of 1947,

TABLE IV

THE NATIONAL HEALTH ACT OF 1947. (S.545.)* $\ddagger$

THE NATIONAL INSURANCE AND PUBLIC HEALTH ACT OF 1947. (S.1320.)†‡

Main Provisions

1. Co-ordination of the health functions of the Federal Government in a single National Health Agency.

2. Provision of medical and dental services. Groups eligible are:

(a) Persons unable to afford the cost of medical or dental care.

(b) School children (dental services only).

3. Expansion of Public Health Services.

4. Promotion of medical education and research.

1. Provision of a compulsory national health insurance programme. Groups eligible are:

(a) All insured workers and their dependants.

(b) Non-insured persons in need, and other individuals not eligible under $(a)$ for any period for which adequate reimbursement is made to the Treasury Account by public agencies.

2. Expansion of Public Health and other services (e.g. Maternal and Child Health).

3. Promotion of medical education and research.

Administration and Finance

Central. The scheme is administered centrally by the National Health Agency. It is financed by funds as appropriated by Congress.

State. Federal financial support is given to States which:

(a) Submit satisfactory plans and

(b) Participate financially. The amount of the Federal contribution depends on local needs.
The scheme is administered by the existing Federal services under the Federal Security Administrator. It is financed by a "Personal Health Services Account " created in the Treasury to which shall be appropriated: (1) Sums equal to 3 per cent. of all wages up to $\$ 3,600$ a year. (2) Sums equal to the estimated cost of dental and home nursing services. (3) Any further sums required to meet expenditure.

1. The Personal Health Services are financed from the Treasury Account (i.e. from funds derived from compulsory insurance).

2. The Public Health Services, Maternal and Child Health Services, etc., are supported by Federal funds (derived from taxation) in States which (a) submit satisfactory plans, and (b) participate financially. The amount of the Federal contribution depends on local needs.

3. Where satisfactory plans are not produced by a fixed date, the .Federal Government will assume responsibility for administering the-programme.

- Introduced by Senators Taft, Smith, Ball, and Donnell on February 10, 1947.

+ Introduced by Senators Murray, Wagner, Pepper, Chavez, Taylor, and McGrath on May 20, 1947.

\$ Though referred to as acts, neither of these bills have been passed by Congress. 
S.545); a summary of the main provisions of the two bills is given in Table IV. Though they are referred to as Acts in the United States, these proposals have not been passed by Congress.

The two bills have in common provisions for expanded Public Health services, and for assistance to education and research, but differ sharply in the sections related to medical care. The Taft Act would co-ordinate the health functions of the Federal Government in a single agency, and would restrict government medical and dental services to the poorest groups, and to schoolchildren. The National Insurance and Public Health Act proposes a system of National Health Insurance covering all workers and their dependants, and financed by compulsory deductions from wages.

It is this last feature, which would make the Federal Government responsible for curative services covering the whole country, which has raised most opposition. It is opposed by the American Medical Association on behalf of the medical profession, and by various other bodies which resent the extension of Federal responsibility. This controversy is described more fully under (7).

\section{MEDICAL PERSONNEL}

\section{Numbers AND Distribution}

The United States has approximately one qualified doctor for every seven hundred and sixty persons. Ten years earlier the ratio was one to eight hundred, and the American Medical Association (1948a) estimates that at the present rate of increase of the number of medical graduates it will be one tc seven hundred in 1960. A comparison with the ratios of other countries indicates that by this index the United States is relatively well provided with doctors.

The value of this advantage cannot be assessed, however, without consideration of the question of distribution. Table $\mathbf{V}$ gives for each State the population per physician (1940), and the per capita income (1941). It shows how inadequately the population/physician ratio of the whole country (751) expresses the situation in individual States, where the range is from 296 (District of Columbia) to 1,459 (Mississippi). The disparity between different areas is even wider than these figures suggest, and 141 counties have more than 5,000 persons per doctor (Parran, 1947).

American authorities are quite aware that the correction of these deficiencies is not simply a question of increasing the total number of available physicians. Table $\mathrm{V}$ shows the close correlation which exists between State wealth and medical manpower, and inevitably a high proportion of doctors will continue to be attracted to the wealthier States. In the absence of government responsibility for medical care, which would make it possible to

TABLE $V$

Distribution of Physicians (1940) as Related to Per CAPITA INCOME (1941)

\begin{tabular}{|c|c|c|c|}
\hline State & & $\begin{array}{l}\text { Population } \\
\text { per physician }\end{array}$ & $\begin{array}{c}\text { Per capita } \\
\text { income }\end{array}$ \\
\hline United States & .. & 751 & 693 \\
\hline Mississippi & .. & 1,459 & 283 \\
\hline Alabama & $\ldots$ & 1,365 & 359 \\
\hline South Carolina & .. & 1,355 & 354 \\
\hline North Carolina & & 1,303 & 397 \\
\hline South Dakota & & 1,266 & 484 \\
\hline Idaho $\quad .$. & .. & 1,241 & 543 \\
\hline North Dakota & & 1,239 & 534 \\
\hline New Mexico & .. & 1,211 & 415 \\
\hline Georgia .. & .. & 1,106 & 389 \\
\hline Arkansas & .. & 1,066 & 332 \\
\hline Montana & $\because$ & 1,042 & 682 \\
\hline West Virginia & $\therefore$ & 1,037 & 477 \\
\hline Kentucky & .. & 1,031 & 369 \\
\hline Tennessee & .. & 1,003 & 413 \\
\hline Oklahoma & .. & 993 & 417 \\
\hline Louisiana & .. & 959 & 433 \\
\hline Utah .. & .. & 957 & 592 \\
\hline Texas & .. & 930 & 497 \\
\hline Virginia .. & .. & 927 & 565 \\
\hline Wyoming & .. & 915 & 696 \\
\hline Wisconsin & .. & 891 & 649 \\
\hline Kansas .. & .. & 870 & 549 \\
\hline Maine .. & .. & 854 & 602 \\
\hline Arizona ... & $\ldots$ & 840 & 562 \\
\hline Florida .. & .. & 834 & 531 \\
\hline Indiana $\ldots$ & .. & 829 & 705 \\
\hline Michigan & . & 826 & 790 \\
\hline Iowa & & 823 & 609 \\
\hline Nebraska & . & 805 & 510 \\
\hline Minnesota & .. & 792 & 589 \\
\hline Washington & .. & 789 & 833 \\
\hline Delaware & $\therefore$ & 786 & 1,023 \\
\hline New Hampshire & & 749 & 629 \\
\hline Oregon ... & .. & 746 & 752 \\
\hline Rhode Island & .. & 742 & 900 \\
\hline Ohio & & 741 & 815 \\
\hline Pennsylvania & .. & 732 & 751 \\
\hline New Jersey & .. & 716 & 912 \\
\hline Missouri & & 714 & 621 \\
\hline Vermont & .. & 687 & 613 \\
\hline Nevada & $\ldots$ & 660 & 912 \\
\hline Connecticut & $\ldots$ & 658 & 1,059 \\
\hline Illinois & .. & 648 & 865 \\
\hline Maryland & .. & 609 & 851 \\
\hline California & .. & 580 & 974 \\
\hline Colorado & .. & 572 & 620 \\
\hline Massachusetts & 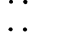 & 547 & 883 \\
\hline New York & 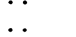 & 492 & 994 \\
\hline District of Colur & mbia & 296 & 1,101 \\
\hline
\end{tabular}

Source: "North Carolina Medical Care Commission National Committee for the Medical School Survey Final Report.' 
offer inducements in less popular areas, two alternative considerations have been discussed. Doctors are reluctant to serve where hospital facilities are poor, and the Hospital Survey and Construction Act of 1946 (see page 92) has been directed to' this as well as to other ends. It has also been recognized that students recruited from under-doctored (usually rural) areas are more likely to return to them after qualification, and a system of selective recruitment on this basis has been suggested (Bachmeyer, 1947). Unfortunately the States continue to exercise their right to insist on independent licensing examinations. This tradition may have contributed something to standards of practice at a time when the requirements of medical schools were less exacting than they are to-day, but in present circumstances it is an anachronism which impedes the progress of medical services.

\section{SPECIALISTS}

In the United States any doctor is entitled to call himself a specialist, and to list himself as such in the American Medical Directory. The proportion who do so is increasing, and in the period 1928 to 1942 rose from 26 per cent. to 51 per cent. of all doctors (Stern, 1945a). In 1942 the numbers were (Report of the Committee on Medical Preparedness, 1942):

\begin{tabular}{|c|c|c|}
\hline $\begin{array}{l}\text { General practitioners } \\
\text { Full specialists } \\
\text { Partial specialists }\end{array}$ & . & $\begin{array}{l}. \quad 86,000 \\
. \quad 38,800 \\
. \quad 51,400\end{array}$ \\
\hline Total & & 176,200 \\
\hline ve practice & & 155,000 \\
\hline
\end{tabular}

A more rigorous system of certification by Examining Boards in Medical Specialties has been established by Specialist Societies, and since 1933 the Council on Medical Education and Hospitals of the American Medical Association has undertaken the formulation of standards and the approval of the examining boards. While the possession of the certificate of a board is not technically necessary (as is sometimes the case in Great Britain. with the membership of the Royal College of Physicians or the fellowship of the Royal College of Surgeons), in practice it is becoming increasingly important to the prospective applicant for a specialist appointment. In 1947 approval had been given to fifteen boards (Table VI), and in 1948 a sixteenth (the American Board of Physical Medicine) was added.

Table VI shows the distribution of the 28,476 certified specialists between the various specialties. The number includes 882 certified in sub-specialties by the boards in internal medicine, paediatrics, and surgery.
TABLE VI

Approved Examining Boards in Medical Specialties

\begin{tabular}{|c|c|c|c|}
\hline Name of Board & $\begin{array}{c}\text { Year of } \\
\text { incorpor- } \\
\text { ation }\end{array}$ & $\begin{array}{c}\text { Total } \\
\text { certifi- } \\
\text { cates } \\
\text { awarded } \\
\text { to } \\
\text { March 1, } \\
1947\end{array}$ & $\begin{array}{l}\% \text { of } \\
\text { total }\end{array}$ \\
\hline $\begin{array}{l}\text { Paediatrics ... .. } \\
\text { Psychiatrsand Neurology } \\
\text { Orthopaedic Surgery } \\
\text { Dermatology and Syphilo- }\end{array}$ & $\begin{array}{l}1933 \\
1934 \\
1934\end{array}$ & $\begin{array}{l}2,572 \\
2,438 \\
1,042\end{array}$ & $\begin{array}{l}9 \cdot 03 \\
8 \cdot 56 \\
3 \cdot 66\end{array}$ \\
\hline $\begin{array}{llll}\operatorname{logy} & . & . . & . \\
\text { Radiology } & . . & . . & . \\
\text { Urology } & . & . & .\end{array}$ & $\begin{array}{l}1932 \\
1934 \\
1935\end{array}$ & $\begin{array}{r}844 \\
2,366 \\
1,136\end{array}$ & $\begin{array}{l}2 \cdot 96 \\
8 \cdot 32 \\
3 \cdot 99\end{array}$ \\
\hline $\begin{array}{c}\text { Obstetrics and Gynaeco- } \\
\text { logy }\end{array}$ & 1930 & 2.137 & $7 \cdot 50$ \\
\hline Internal Medicine & 1936 & 4,449 & $15 \cdot 63$ \\
\hline Pathology ... & 1936 & 1,359 & $4 \cdot 77$ \\
\hline Ophthalmology & 1917 & 2,564 & $9 \cdot 00$ \\
\hline Otolaryngology & 1924 & 3,988 & $14 \cdot 00$ \\
\hline Surgery & 1937 & 2,904 & $10 \cdot 20$ \\
\hline Anaesthesiology & 1938 & 316 & $1 \cdot 11$ \\
\hline Plastic Surgery & 1937 & 171 & $0 \cdot 60$ \\
\hline Neurological Surgery & 1940 & 190 & 0.67 \\
\hline Totals & & 28,476 & $100 \cdot 00$ \\
\hline
\end{tabular}

Source: Approved Examining Boards in Medical Specialties. J. Amer. med. Ass., 134, 1394 (August 16), 1947.

\begin{tabular}{|c|c|c|c|c|c|}
\hline \multirow{2}{*}{\multicolumn{6}{|c|}{ Internal Medicine }} \\
\hline & & & & & \\
\hline Allergy & & & & & \\
\hline Cardiovascu & ar diseas & & & & 361 \\
\hline Gastroenter & $\log y$ & & & & \\
\hline $\begin{array}{l}\text { Pulmonary } \\
\text { " tubercu }\end{array}$ & iseases ( & & & & 163 \\
\hline Paediatrics & & & & & \\
\hline Allergy & .. & .. & . & & 5 \\
\hline Surgery & & & & & \\
\hline Proctology & . & . & .. & & 75 \\
\hline Total & .. & .. & $\cdots$ & 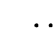 & 882 \\
\hline
\end{tabular}

The number of doctors in each specialty can be related to the total population, but we have no real basis for assessment of the adequacy of the ratio which results. Some authorities are disturbed by the rapidity of the apparent increase in the proportion of specialists (as shown by the proportion of doctors who so describe themselves) but it is unlikely that the number actually certified by the boards is at present in excess of requirements. Unfortunately the defective distribution described above, for all doctors, is even more marked in the case of specialists and the problem of re-distribution is more difficult. In 194150 per cent. of the certified ophthalmologists practised in five States, and there were parallel examples in other specialties (Stern, 1945b). 


\section{Future Personinel ReQuirements}

The Surgeon General has recently estimated that if the number of. doctors in training is not increased there will be a shortage of $30,000-55,000$ by 1960 (Parran, 1947). He assumes that 111,000 doctors will qualify in the period 1940-60 $(5,200$ yearly for twenty years, plus 7,000 additional graduates from courses accelerated during the war), and that 77,000 will be lost through death or retirement. Against the anticipated net increase of 34,000 he puts the following estimates of additional medical manpower requirements, and draws attention to the fact that an allowance for increased public demand for medical attention would put the total even higher. (For example, 25,000 more physicians would be required to make the physician/population ratio of the remaining thirty-six States as high as the mean ratio of the first twelve, which would give a figure of roughly 55,000 for the overall deficit (Parran, 1948).)

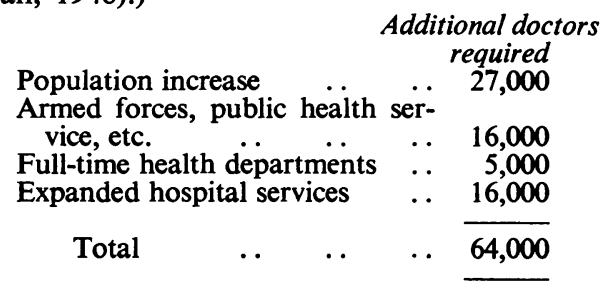

In the opinion of the American Medical Association, the expansion of at least 50 per cent. in the number of medical graduates which these figures suggest is neither necessary nor possible (1948a). Their estimate of the mean number of annual graduates for the next twelve years (at least 5,500) is higher than that of the Surgeon General. They criticize his estimate of losses from death and retirement, and his use of the physician/population ratios of the upper twelve States as a basis of calculation for the remaining thirty-six. They are most seriously disturbed, however, by the possibility that any considerable and rapid increase in the number of graduates may be achieved at the sacrifice of standards of education which over a period of years they have attempted to raise.

A choice between these widely separated views requires certain assumptions about future medical services. For example, the figures given by the Surgeon General for additional doctors in the public health service, in full-time health departments, and in hospitals, presuppose a fairly rapid expansion of these services, which it is perhaps not unreasonable to anticipate during the next twelve years. The estimate of manpower needed to improve the population/physician ratio of each State is more speculative, not only because the optimum ratio must depend on the efficiency of medical services, but also because in the absence of any mechanism which influences distribution an increase in the number of physicians will only slowly raise the ratio in the poorest areas. Yet if the relevant decisions cannot be predicted with certainty, experience in other countries indicates that a progressive development is usually impeded by a shortage of staff. And, since even the United States is in no danger of having too many well-qualified doctors, it seems reasonable to suggest that the number should be increased as rapidly as is consistent with the maintenance of educational standards, the potential figure being more profitably a matter for enquiry rather than for debate.

\section{The Sale of Practice}

The sale of practice, which in the past has been a characteristic feature of British medicine, is uncommon in the United States. When practices are sold, it is unusual for the selling-price to include an item in respect of good will, and many American doctors are surprised to learn that anyone should consider it worth his while to pay heavily for privileges which no law prevents him acquiring for himself. The difference in English and American traditions in this matter is attributable to the wider opportunities in American practice, since a new doctor can compete on reasonable terms with established practitioners if the population is increasing rapidly or is changing in composition. As these conditions change, and in the absence of legislative control, the sale of practice for a price which includes an allowance for good will is likely to become more common.

The Bureau of Medical Economics (Dickinson, 1948) has recently investigated current experience through the State medical societies, and in advising prospective buyers reports cautiously on estimates not covered by tangible assets. The doubt arises, however, not on the ethics of payment for good will, but on the difficulty of arriving at any fair estimate of its monetary value. The Bureau endorses the following view of a State secretary:

\footnotetext{
"The location, the type of practice, the size of the practice and the competition that is present are all factors which must be considered in each individual sale, and it appears that probably there is no formula that can be set up -even with an area such as a State-that would assist in any individual transaction. I am inclined to look on this as an individual business venture that would depend entirely on an agreement between the parties concerned. Even though in the eyes of everyone else the purchase price was too high or too low, if it was agreeable to the two parties concerned, it
} 
would still be a happy transaction. And for those reasons, it has been the opinion of the society that it would not interfere or attempt to offer any assistance to persons contemplating the purchase of a practice."

\section{HOSPITALS}

Since 1921 the Council on Medical Education and Hospitals has published in the Journal of the American Medical Association the results of an annual census of American hospitals. This census now includes all hospitals which conform to minimum standards laid down by the American Medical Association, and is the single most useful source of annual statistical data. Lists of approved hospitals are also published annually by the American College of Surgeons (since 1918), and of member institutions by the American Hospital Association. At intervals the Division of Vital Statistics of the United States Bureau of the Census conducts surveys, of which the most recent was in 1940. Together these sources provide useful data on hospital facilities, though detailed figures vary with the standards accepted for approval.

\section{GrowTH AND CONTROL}

American hospitals have had a rapid if unplanned development, under both voluntary and government agencies (Table VII). In 1909, the earliest date for which reliable figures are available, there were 4,359 hospitals, and 421,065 beds. At that time the Federal Government controlled only $2 \cdot 1$ per cent. of beds, as compared with 44.9 per cent. under State control and 53.0 per cent. under other ownership. By 1946 the total numbers of hospitals and beds were 6,280 and $1,468,714$ respectively. During this period Federal beds increased about 30 times, to 262,486 in 1946 , when the proportions were: Federal 18.0 per cent.; State 42.8 per cent.; other $39 \cdot 2$ per cent. The number of hospitals and beds under Federal control dropped sharply in 1946, a decrease attributable to the rapid reduction in Federal commitments which followed the end of the war.

Table VIII shows that in $194631 \cdot 3$ per cent. of hospitals were maintained by government, and 68.7 per cent. by non-government agencies $(73.8$ per cent. and $26 \cdot 2$ per cent. respectively of hospital beds). The State was the most important government agency, with responsibility for 42.8 per cent. of beds, compared with 18.0 per cent. Federal, $7 \cdot 0$ per cent. county, 5.2 per cent. city, and 0.8 per cent. city-county. Non-profit hospitals not under government control are divided between church and lay authorities, and were responsible for 22.9 per cent. of the hospital beds of the country. The proportion of American hospitals operated for profit has always been small, and is decreasing. In 1946 the American Medical Association listed 48,999 beds in 1,326 proprietary hospitals, or about $3 \cdot 3$ per cent. of all hospital beds, which during 1946 cared for 8.9 per cent. of all patients. The actual number of profit-making institutions is higher than these figures suggest, since the American Medical Association does not register hospitals which do not reach its standards for approval.

The number of hospitals, beds, and annual admissions are given separately for different types of hospitals in Table IX. General hospitals, which had 43.7 per cent. of beds, received 92.7 per cent. of all hospital admissions in 1946 . These figures are very different from those for nervous and mental hospitals, where 46.0 per cent. of beds accommodated 1.8 per cent. of patients, and for tuberculosis hospitals, where 5.7 per cent. of beds accommodated

TABLE VII

Summary of the Growth of Hospitals, 1909 to $1946^{*}$

\begin{tabular}{|c|c|c|c|c|c|c|c|c|}
\hline \multirow{2}{*}{ Year } & \multicolumn{2}{|c|}{ Federal Hospitals } & \multicolumn{2}{|c|}{ State Hospitals } & \multicolumn{2}{|c|}{ All other Hospitals } & \multicolumn{2}{|c|}{ Total } \\
\hline & Number & Capacity & Number & Capacity & Number & Capacity & Number & Capacity \\
\hline $\begin{array}{l}1909 \\
1914 \\
1918 \\
1923 \\
1928 \\
1933 \\
1938 \\
1943 \\
1946\end{array}$ & $\begin{array}{r}71 \\
73 \\
110 \\
220 \\
294 \\
295 \\
330 \\
827 \\
464\end{array}$ & $\begin{array}{r}8,827 \\
12,602 \\
18,815 \\
53,869 \\
61,765 \\
75,635 \\
92,248 \\
476,673 \\
262,486\end{array}$ & $\begin{array}{l}232 \\
294 \\
303 \\
601 \\
595 \\
557 \\
523 \\
531 \\
557\end{array}$ & $\begin{array}{l}189,049 \\
232,834 \\
262,254 \\
302,208 \\
369,759 \\
459,646 \\
541,279 \\
610,115 \\
628,363\end{array}$ & $\begin{array}{l}4,056 \\
4,650 \\
4,910 \\
6,009 \\
5,963 \\
5,585 \\
5,313 \\
5,297 \\
5,259\end{array}$ & $\begin{array}{l}223,189 \\
287,045 \\
331,182 \\
399,645 \\
461,410 \\
491,765 \\
527,853 \\
562,466 \\
575,865\end{array}$ & $\begin{array}{l}4,359 \\
5,037 \\
5,323 \\
6,830 \\
6,852 \\
6,437 \\
6,166 \\
6,655 \\
6,280\end{array}$ & $\begin{array}{r}421,065 \\
532,481 \\
612,251 \\
755,722 \\
892,934 \\
1,027,046 \\
1,161,380 \\
1,649,254 \\
1,468,714\end{array}$ \\
\hline
\end{tabular}

"Source: "Hospital Service in the United States." J. Amer. med. Ass., 133, 1066 (1947) (modified). 
TABLE VIII

Hospital Control, 1946*

\begin{tabular}{|c|c|c|c|c|c|c|c|c|c|c|}
\hline & & & & & \multicolumn{2}{|c|}{ Hospitals } & \multicolumn{2}{|c|}{ Beds } & \multicolumn{2}{|c|}{ Admissions } \\
\hline \multicolumn{5}{|l|}{. } & No. & $\%$ & No. & $\%$ & No. & $\%$ \\
\hline $\begin{array}{ll}\begin{array}{l}\text { Governmental } \\
\text { Federal }\end{array} & \\
\text { State } & . \\
\text { County } & . \\
\text { City } & \ldots \\
\text { City-County }\end{array}$ & $\begin{array}{l}\cdots \\
\cdots \\
\cdots \\
\cdots\end{array}$ & $\begin{array}{l}\cdots \\
\because \\
\cdots \\
\cdots\end{array}$ & $\begin{array}{l}\cdots \\
\cdots \\
\cdots \\
\cdots\end{array}$ & $\begin{array}{l}. \\
. \\
. \\
. \\
.\end{array}$ & $\begin{array}{r}464 \\
557 \\
514 \\
363 \\
64\end{array}$ & $\begin{array}{l}7 \cdot 4 \\
8 \cdot 9 \\
8 \cdot 2 \\
5 \cdot 8 \\
1 \cdot 0\end{array}$ & $\begin{array}{r}264,486 \\
628,363 \\
102,071 \\
76,534 \\
11,280\end{array}$ & $\begin{array}{r}18 \cdot 0 \\
42 \cdot 8 \\
7 \cdot 0 \\
5 \cdot 2 \\
0 \cdot 8\end{array}$ & $\begin{array}{r}1,949,711 \\
648,538 \\
704,772 \\
1,109,573 \\
185,569\end{array}$ & $\begin{array}{r}12 \cdot 9 \\
4 \cdot 3 \\
4 \cdot 7 \\
7 \cdot 3 \\
1 \cdot 2\end{array}$ \\
\hline \multicolumn{2}{|l|}{ Total Governmental } & .. & .. &. & 1,962 & $31 \cdot 3$ & $1,082,734$ & $73 \cdot 8$ & $4,598,163$. & $30 \cdot 4$ \\
\hline \multicolumn{2}{|c|}{$\begin{array}{l}\text { Non-Governmental } \\
\text { Church } \\
\text { Non-profit associations }\end{array}$} & $\begin{array}{l}. \\
.\end{array}$ & $\ddot{*}$ & $\begin{array}{c}. \cdot \\
.\end{array}$ & $\begin{array}{l}1,050 \\
1,942\end{array}$ & $\begin{array}{l}16 \cdot 7 \\
30 \cdot 9\end{array}$ & $\begin{array}{l}138,096 \\
198,885\end{array}$ & $\begin{array}{r}9 \cdot 4 \\
13 \cdot 4\end{array}$ & $\begin{array}{l}4,098,042 \\
5,100,117\end{array}$ & $\begin{array}{l}27 \cdot 0 \\
33 \cdot 7\end{array}$ \\
\hline Total non-profit & .. & .. & .. &.. & 2,992 & $47 \cdot 6$ & 336,981 & $22 \cdot 8$ & $9,198,159$ & $60 \cdot 7$ \\
\hline \multicolumn{4}{|c|}{$\begin{array}{l}\text { Individual and partnership } \\
\text { Corporations (profit unrestricted) }\end{array}$} &.. & $\begin{array}{l}980 \\
346\end{array}$ & $\begin{array}{r}15 \cdot 6 \\
5 \cdot 5\end{array}$ & $\begin{array}{l}28,116 \\
20,883\end{array}$ & $\begin{array}{l}1 \cdot 9 \\
1 \cdot 4\end{array}$ & $\begin{array}{l}817,301 \\
539,829\end{array}$ & $\begin{array}{l}5 \cdot 4 \\
3 \cdot 5\end{array}$ \\
\hline Total proprietary & $\ldots$ & .. & .. &. & 1,326 & $21 \cdot 1$ & 48,999 & $3 \cdot 3$ & $1,357,130$ & $8 \cdot 9$ \\
\hline \multicolumn{2}{|c|}{ Total non-governmental } & . & $\cdots$ &. & 4,318 & $68 \cdot 7$ & 385,980 & $26 \cdot 2$ & $10,555,289$ & $69 \cdot 6$ \\
\hline Total, all hospitals & $\cdots$ & .. & .. &.. & 6,280 & 100 & $1,468,714$ & 100 & $15,153,452$ & 100 \\
\hline
\end{tabular}

"Source: "Hospital Service in the United States." J. Amer. med. Ass., 133, 1066 (1947) (modified).

TABLE IX

Hospital Service, 1946*

\begin{tabular}{|c|c|c|c|c|c|c|c|c|c|}
\hline & & & \multicolumn{2}{|c|}{ Hospitals } & \multicolumn{2}{|c|}{ Beds } & \multicolumn{2}{|c|}{ Admissions } & \multirow{2}{*}{$\begin{array}{l}\text { Patients } \\
\text { per bed } \\
\text { per year }\end{array}$} \\
\hline & & & No. & $\%$ & No. & $\%$ & No: & $\%$ & \\
\hline $\begin{array}{l}\text { General } \\
\text { Nervous and } \\
\text { Tuberculosis } \\
\text { Maternity } \\
\text { Industrial } \ldots \\
\text { Ear, nose, and throat } \\
\begin{array}{l}\text { Children's } \\
\text { Orthopaedic }\end{array} \\
\begin{array}{l}\text { Orolation } \\
\text { Isol. }\end{array} \\
\begin{array}{l}\text { Convalescent } \\
\text { Institutions }\end{array} \\
\text { All other hospitals }\end{array}$ & 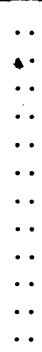 & $\begin{array}{l}. . \\
. \\
. \\
. \\
. \\
. \\
. \\
. \\
. .\end{array}$ & $\begin{array}{r}4,523 \\
575 \\
.450 \\
101 \\
34 \\
46 \\
42 \\
82 \\
70 \\
97 \\
202 \\
58\end{array}$ & $\begin{array}{l}72 \cdot 1 \\
9 \cdot 2 \\
7 \cdot 2 \\
1 \cdot 6 \\
0 \cdot 5 \\
0 \cdot 7 \\
0 \cdot 7 \\
1 \cdot 3 \\
1 \cdot 1 \\
1 \cdot 5 \\
3 \cdot 2 \\
0 \cdot 9\end{array}$ & $\begin{array}{r}641,331 \\
674,930 \\
83,187 \\
5,392 \\
2,980 \\
2,749 \\
4,490 \\
6,518 \\
11,497 \\
6,579 \\
21,253 \\
7,808\end{array}$ & $\begin{array}{l}43 \cdot 7 \\
46 \cdot 0 \\
5 \cdot 7 \\
0 \cdot 4 \\
0 \cdot 2 \\
0 \cdot 2 \\
0 \cdot 3 \\
0 \cdot 4 \\
0 \cdot 8 \\
0.4 \\
1.4 \\
0.5\end{array}$ & $\begin{array}{r}14,051,508 \\
271,209 \\
99,741 \\
82,191 \\
56,061 \\
111,417 \\
96,026 \\
23,960 \\
146,836 \\
32,608 \\
144,664 \\
34,231\end{array}$ & $\begin{array}{l}92 \cdot 7 \\
1.8 \\
0.7 \\
0.5 \\
0.4 \\
0.7 \\
0.6 \\
0 \cdot 2 \\
1 \cdot 0 \\
0 \cdot 2 \\
1.0 \\
0.2\end{array}$ & $\begin{array}{r}21 \cdot 9 \\
0 \cdot 4 \\
1 \cdot 2 \\
15 \cdot 2 \\
18 \cdot 8 \\
40 \cdot 5 \\
21 \cdot 3 \\
4 \cdot 1 \\
12 \cdot 8 \\
5 \cdot 0 \\
6 \cdot 8 \\
4 \cdot 4\end{array}$ \\
\hline Total all hospitals & & 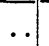 & 6,280 & 100 & $1,468,714$ & 100 & $15,153,452$ & 100 & $10 \cdot 3$ \\
\hline
\end{tabular}

* Source: “Hospital Service in the United States." J. Amer. med. Ass., 133, 1066 (1947) (modified). 
TABLE $\mathrm{X}$

Control of Hospitals of Different Types, 1946*

\begin{tabular}{|c|c|c|c|c|c|c|c|c|c|c|}
\hline & & & & & \multicolumn{2}{|c|}{ Hospitals } & \multicolumn{2}{|c|}{ Beds } & \multicolumn{2}{|c|}{ Admissions } \\
\hline & & & & & No. & $\%$ & No. & $\%$ & No. & $\%$ \\
\hline $\begin{array}{ll}\text { General } & \\
\quad \text { Federal } & . \\
\text { State } & . \\
\text { County } & \ldots \\
\text { City } & \ldots \\
\text { City-County }\end{array}$ & $\begin{array}{l}\cdots \\
\cdots \\
\cdots \\
\cdots \\
\cdots\end{array}$ & $\begin{array}{l}\cdots \\
\cdots \\
\cdots \\
\cdots \\
\cdots\end{array}$ & $\begin{array}{l}\cdots \\
\cdots \\
\cdots \\
\cdots \\
\cdots\end{array}$ & $\begin{array}{l}. \\
\cdots \\
\cdots \\
\cdots \\
\cdots\end{array}$ & $\begin{array}{r}373 \\
55 \\
250 \\
281 \\
43\end{array}$ & $\begin{array}{l}8 \cdot 2 \\
1 \cdot 2 \\
5 \cdot 5 \\
6 \cdot 2 \\
1 \cdot 0\end{array}$ & $\begin{array}{r}192,551 \\
20,721 \\
43,494 \\
51,701 \\
8,653\end{array}$ & $\begin{array}{r}30 \cdot 0 \\
3 \cdot 2 \\
6 \cdot 8 \\
8 \cdot 1 \\
1 \cdot 3\end{array}$ & $\begin{array}{r}1,853,705 \\
304,515 \\
643,717 \\
1,041,397 \\
180,306\end{array}$ & $\begin{array}{r}13 \cdot 1 \\
2 \cdot 2 \\
4 \cdot 6 \\
7 \cdot 4 \\
1 \cdot 3\end{array}$ \\
\hline $\begin{array}{l}\text { Total Governmenta } \\
\text { Total non-governme }\end{array}$ & ental & $\begin{array}{l}. \\
\cdots \\
\end{array}$ & $\begin{array}{l}\cdots \\
\cdots \\
\end{array}$ & $\begin{array}{l}. \\
\cdots\end{array}$ & $\begin{array}{l}1,002 \\
3,521 \\
\end{array}$ & $\begin{array}{l}22 \cdot 1 \\
77 \cdot 9 \\
\end{array}$ & $\begin{array}{l}317,120 \\
324,331 \\
\end{array}$ & $\begin{array}{l}49 \cdot 4 \\
50 \cdot 6\end{array}$ & $\begin{array}{r}4,005,640 \\
10,045,868 \\
\end{array}$ & $\begin{array}{l}28 \cdot 6 \\
71 \cdot 4 \\
\end{array}$ \\
\hline Total General & . & . & $\ldots$ & $\ldots$ & 4,523 & 100 & 641,331 & 100 & $14,051,508$ & 100 \\
\hline $\begin{array}{ll}\text { Nervous and } & \text { Mental } \\
\text { Federal } & . \\
\text { State } & \ldots \\
\text { County } & \ldots \\
\text { City } & \ldots \\
\text { City-County } \\
\end{array}$ & $\begin{array}{l}l \\
\cdots \\
\cdots \\
\cdots \\
\cdots \\
\cdots\end{array}$ & $\begin{array}{l}. . \\
\cdots \\
\cdots \\
\cdots \\
\cdots\end{array}$ & $\begin{array}{l}\cdots \\
\cdots \\
\cdots \\
\cdots \\
\cdots\end{array}$ & $\begin{array}{l}. \\
. \\
. \\
. \\
.\end{array}$ & $\begin{array}{r}36 \\
280 \\
49 \\
-5 \\
-\end{array}$ & $\begin{array}{r}6 \cdot 3 \\
48 \cdot 7 \\
8 \cdot 5 \\
0 \cdot 9 \\
-\end{array}$ & $\begin{array}{r}59,254 \\
565,721 \\
27,042 \\
4,916 \\
-\end{array}$ & $\begin{array}{r}8 \cdot 8 \\
83 \cdot 8 \\
4 \cdot 0 \\
0 \cdot 7 \\
-\end{array}$ & $\begin{array}{r}51,590 \\
143,808 \\
8,492 \\
1,611 \\
-\end{array}$ & $\begin{array}{r}19 \cdot 0 \\
53 \cdot 0 \\
3 \cdot 1 \\
0.6 \\
-\end{array}$ \\
\hline $\begin{array}{l}\text { Total Governmenta } \\
\text { Total non-governm }\end{array}$ & il & $\begin{array}{l}. \\
\therefore\end{array}$ & $\begin{array}{l}\cdots \\
\cdots\end{array}$ & $\begin{array}{l}. \\
.\end{array}$ & $\begin{array}{l}370 \\
205\end{array}$ & $\begin{array}{l}64 \cdot 4 \\
35 \cdot 6\end{array}$ & $\begin{array}{r}656,933 \\
17,997\end{array}$ & $\begin{array}{r}97 \cdot 3 \\
2 \cdot 7\end{array}$ & $\begin{array}{r}205,501 \\
65,708\end{array}$ & $\begin{array}{l}75 \cdot 7 \\
24 \cdot 3\end{array}$ \\
\hline Total Nervous and & Mental & $\cdots$ & . &. & 575 & 100 & 674,930 & 100 & 271,209 & 100 \\
\hline $\begin{array}{ll}\text { Tuberculosis } & \\
\text { Federal } & . \\
\text { State } & \ldots \\
\text { County } & \ldots \\
\text { City } & \ldots \\
\text { City-County }\end{array}$ & $\begin{array}{l}. . \\
\cdots \\
\cdots \\
\cdots \\
.\end{array}$ & $\begin{array}{l}\cdots \\
\cdots \\
\cdots \\
\cdots\end{array}$ & $\begin{array}{l}\cdots \\
\cdots \\
\cdots \\
\cdots\end{array}$ & $\begin{array}{l}. \\
\cdots \\
\cdots \\
. \\
.\end{array}$ & $\begin{array}{r}23 \\
77 \\
180 \\
25 \\
15\end{array}$ & $\begin{array}{r}5 \cdot 1 \\
17 \cdot 1 \\
40 \cdot 0 \\
5 \cdot 6 \\
3 \cdot 3\end{array}$ & $\begin{array}{r}8,536 \\
26,862 \\
23,577 \\
10,192 \\
2,242 \\
\end{array}$ & $\begin{array}{r}10 \cdot 3 \\
32 \cdot 3 \\
28 \cdot 3 \\
12 \cdot 3 \\
2 \cdot 7 \\
\end{array}$ & $\begin{array}{r}16,778 \\
22,313 \\
22,417 \\
19,357 \\
2,067 \\
\end{array}$ & $\begin{array}{r}16 \cdot 8 \\
22 \cdot 4 \\
22 \cdot 5 \\
19 \cdot 4 \\
2 \cdot 1 \\
\end{array}$ \\
\hline $\begin{array}{l}\text { Total Governmenta } \\
\text { Total Non-governm }\end{array}$ & nental & $\begin{array}{l}. \\
\cdots\end{array}$ & $\begin{array}{l}\cdots \\
\cdots \\
\end{array}$ & $\begin{array}{l}. . \\
. .\end{array}$ & $\begin{array}{l}320 \\
130 \\
\end{array}$ & $\begin{array}{l}71 \cdot 1 \\
28 \cdot 9\end{array}$ & $\begin{array}{l}71,409 \\
11,778\end{array}$ & $\begin{array}{l}85 \cdot 9 \\
85 \cdot 1\end{array}$ & $\begin{array}{l}82,932 \\
16,809\end{array}$ & $\begin{array}{l}83 \cdot 2 \\
16 \cdot 8 \\
\end{array}$ \\
\hline Total Tuberculosis & .. & . & .. & .. & 450 & 100 & 83,187 & 100 & 99,741 & 100 \\
\hline $\begin{array}{ll}\begin{array}{l}\text { Other } \\
\text { Federal }\end{array} \quad . . \\
\text { State } & \because \\
\text { County } & \therefore \\
\text { City } & \ldots \\
\text { City-County } \\
\end{array}$ & $\begin{array}{l}. . \\
\cdots \\
\cdots \\
.\end{array}$ & $\begin{array}{l}\cdots \\
\cdots \\
\cdots \\
\cdots \\
\cdots\end{array}$ & $\begin{array}{l}\ldots \\
\ldots \\
\cdots \\
\cdots \\
.\end{array}$ & $\begin{array}{l}. \\
. \\
. \\
\cdots \\
.\end{array}$ & $\begin{array}{r}32 \\
145 \\
35 \\
52 \\
6 \\
\end{array}$ & $\begin{array}{r}4 \cdot 4 \\
19 \cdot 8 \\
4.8 \\
7 \cdot 1 \\
0.8 \\
\end{array}$ & $\begin{array}{r}4,145 \\
15,059 \\
7,958 \\
9,725 \\
385 \\
\end{array}$ & $\begin{array}{r}6 \cdot 0 \\
21 \cdot 7 \\
11 \cdot 5 \\
14 \cdot 0 \\
0.6 \\
\end{array}$ & $\begin{array}{r}45,638 \\
177,902 \\
30,146 \\
47,208 \\
3,196 \\
\end{array}$ & $\begin{array}{r}6 \cdot 2 \\
24 \cdot 3 \\
4 \cdot 1 \\
6 \cdot 5 \\
0 \cdot 4 \\
\end{array}$ \\
\hline Total Governmenta & & .. & .. & .. & 270 & $36 \cdot 9$ & 37,272 & $53 \cdot 8$ & 304,090 & $41 \cdot 5$ \\
\hline Total Non-governm & nental & $\cdots$ & $\cdots$ & .. & 462 & $63 \cdot 1$ & 31,994 & $46 \cdot 2$ & 426,904 & $58 \cdot 5$ \\
\hline Total other .. & $\cdots$ & . &. &.. & 732 & 100 & 69,266 & 100 & 730,994 & 100 \\
\hline
\end{tabular}

"Source: “Hospital Service in the United States." J. Amer. med. Ass., 133, 1067 (1947) (modified). 
0.7 per cent. of patients. The differences are reflected in the mean number of patients per bed per year and are, of course, accounted for by the disparity in the times which patients spend in hospitals for these diseases.

The relative contributions of government and non-government authorities to the operation of different types of hospitals in 1946 are indicated in Table X. In the past general hospitals have been provided mainly by voluntary bodies but in recent years the proportion under government control has increased, and in 1946 was roughly 50 per cent. of beds. The Federal Government rapidly increased its responsibility in this field during the war, and in spite of the reduction which followed the end of the war was in 1946 in control of 30.0 per cent. of general hospital beds. Almost all beds for mental illness $(97.3$ per cent. in 1946$)$ are under one or other of the government agencies, the great majority under State control (83.8 per cent. in 1946). About 86 per cent. of the beds for the tuberculous were maintained by the government, the proportions in this case being more equally divided between State, County, City, and Federal agencies.

\section{FinANCE}

A comparison between the capital invested in hospitals by government and voluntary agencies in 1928 and 1946 shows a considerable increase in the proportion derived from taxation, which in 1946 accounted for 66 per cent. of the invested capital.

$\begin{array}{cccc}\text { Taxation } & \begin{array}{c}\text { Voluntary } \\ \text { Contributions }\end{array} & \begin{array}{c}\text { Business } \\ \text { Investments }\end{array} \\ 1928 & \% & \% & \% \\ 1946 & 46 & 45 & 9 \\ & 66 & 31 & 3\end{array}$

The Federal and State governments have always financed most hospitals for mental illness and tuberculosis, but their contribution to general hospitals has in the past been distinctly smaller (under 25 per cent. in 1928). In the depression years, however, there was a marked reduction in voluntary funds, and a parallel increase in the government contribution which has continued until to-day.

Table XI shows the mean annual expenditure and income per bed for different types of hospital under government and other control in 1935. ' In that year the average annual costs per bed were: mental illness, \$309; tuberculosis, \$779; general and special, \$1,098; all hospitals, \$678. The cost is notably higher in all classes for Federal than for other government agencies, but the difference is particularly striking in the case of mental illness. To a considerable extent it is accounted for by the fact that in Federal hospitals the cost of the medical staff is borne by the government authority.

In all classes the income from endowments is low; patients' fees and taxation supported $43 \cdot 1$ per cent. and 47.4 per cent. respectively of the total annual cost, the relative contributions from the two sources being quite different in government and other hospitals.

The fact that costs of hospital operation have risen rapidly and continue to rise causes concern.

$\begin{array}{cc}\text { Year } & \text { Cost per adult patient } \\ 1867 & \text { per day* } \\ 1887 & \$ 1.00 \\ 1907 & \$ 2.00 \\ 1927 & \$ 4.60 \\ 1944 & \$ 8.65 \\ & \$ 11.25\end{array}$

- Source: Corwin, E. H. L. "The American Hospital." Page 52. The Commonwealth Fund, 1946.

They reflect of course a general rise in prices and the increased scope of hospital services, / but since a considerable part of the expenditure is recovered from patients the increase has contributed to the difficulties which many people find in meeting the costs of illness, and has encouraged the rapid growth of voluntary insurance schemes covering hospital charges (see Blue Cross Plans, page 95).

\section{Estimated NeEDS}

American estimates of hospital needs must take account not only of the number of beds available for the whole country, but also of their distribution from State to State (Table XII). A survey covering the period 1935-37 reported that there were 3.14 beds for every thousand persons in the United States, but the ratio in individual States varied from $1 \cdot 26$ to $5 \cdot 34$, and was closely correlated with State per capita income. Here again the disparity is even greater than these figures suggest, and Parran (1947) stated that 40 per cent. of counties had no registered hospital. It has therefore been necessary to plan in terms of State rather than of Federal requirements.

In testimony before the Public Health Subcommittee of the House Committee on Inter-State and Foreign Commerce (Parran, 1946) the Surgeon General stated: "General hospital beds must be increased by about 30 per cent., tuberculosis beds by about 68 per cent., mental hospital beds by about 43 per cent., and chronic disease hospitals and Public Health Centres by several times." In his estimates of the numbers of units needed and of their approximate cost (Table XIII), the Surgeon General included both new and replacement beds. The basis of calculation differs slightly from the one subsequently used in the 1946 Act, but the results are reasonably comparable. The total 
cost was estimated at just under 4 thousand million dollars.

While there has inevitably been some dișagreement about precise requirements, few people would question that the deficiencies are serious, and that responsibility for their correction must rest chiefly with the Federal and State Governments. This has led to the Hospital Survey and Construction Act (discussed below) which became law in August, 1946.

\section{The Hospital Survey and Construction Act}

This Act provides from Federal funds:

(a) Three million dollars, to cover one-third of the cost of State surveys of existing hospital facilities (i.e. two dollars must be provided from State funds for each dollar from the Federal grant). The proportion to each State varies with the population of the State.

(b) Seventy-five million dollars annually for five years to cover one-third of the cost of construction of additional hospitals as required. The proportion to each State varies with the population and wealth of the State.

To be eligible for Federal financial support each State must work through a single State agency and advisory council, on lines prescribed by the Act. The implementation of the Act is in the hands of the States, and Federal control is limited to the power to approve State plans, and to the regulation of the distribution and construction of hospitals.

The standards accepted for future hospital construction are given with the Regulations to the
Act (1947) and in the case of general and tuberculosis hospitals are weighted in relation to the density of population and to the annual deaths respectively.

Beds per thousand population

$\begin{array}{lrr}\text { Mental } & 5 \cdot 0 & \text { All States } \\ \text { Chronic sick } & 2 \cdot 0 & \text { All States }\end{array}$

$\begin{array}{lll}\text { General (a) } 4 \cdot 5 \text { States with } 12 \text { or more persons } & \end{array}$ per square mile

(b) $5 \cdot 0$ States with fewer than 12 and more than 6 persons per square mile

(c) $5 \cdot 5$ States with 6 or fewer persons per square mile.

Beds ner annual death from tuberculosis

Tuberculosis 2.5 Estimated separately for the deaths in each State, 1940-44.

This legislation received widespread support from all sections of medical and political opinion, and for four main reasons has not provoked the controversy which has been a feature of most discussions of Federal participation in the development of curative services.

1. It has made provision for hospital buildings, but not for the staffs required to operate them.

2. The hospitals are to be developed under State and not under Federal control.

3. Only in the case of the indigent, an exception which most authorities allow, has it commented on the methods of payment by patients.

4. The rapid growth of voluntary prepayment hospital plans, sponsored by non-profit corporations, has helped to establish the view that a hospital is not a legitimate centre for private profit (Table XV).

TABLE XI

HoSPITALS EXPENDITURE AND INCOME*

\begin{tabular}{|c|c|c|c|c|c|c|c|c|}
\hline \multirow{2}{*}{$\begin{array}{l}\text { Medical type and } \\
\text { control of profits }\end{array}$} & \multirow{2}{*}{$\begin{array}{c}\text { Number of } \\
\text { profits }\end{array}$} & \multirow{2}{*}{$\begin{array}{c}\text { Number of } \\
\text { beds }\end{array}$} & \multirow{2}{*}{$\begin{array}{l}\text { Annual } \\
\text { expense } \\
\text { per bed } \\
\text { (Dollars) }\end{array}$} & \multirow{2}{*}{$\begin{array}{c}\text { Annual } \\
\text { income } \\
\text { per bed } \\
\text { (Dollars) }\end{array}$} & \multicolumn{4}{|c|}{$\%$ of income from specified sources } \\
\hline & & & & & Patients & Taxes & $\begin{array}{l}\text { Endow- } \\
\text { ments }\end{array}$ & Other \\
\hline $\begin{array}{cc}\text { All hospitals } \\
\text { General and Special } \\
\text { Federal } & . \\
\text { Other Govt. } & . \\
\text { Non-profit } & . \\
\text { Proprietary } & \ldots \\
\text { Mental } & \ldots \\
\text { Federal } & \ldots \\
\text { Other Govt. } & \ldots \\
\text { Non-profit } & \ldots \\
\text { Proprietary } & \ldots \\
\text { Tuberculosis } & \ldots \\
\text { Federal } & \ldots \\
\text { Other Govt. } & \ldots \\
\text { Non-profit } & \ldots \\
\text { Proprietary } & \ldots\end{array}$ & $\begin{array}{r}5,944 \\
4,841 \\
261 \\
569 \\
2,469 \\
1,542 \\
597 \\
27 \\
324 \\
48 \\
198 \\
506 \\
19 \\
299 \\
119 \\
69\end{array}$ & $\begin{array}{r}1,053,977 \\
450,776 \\
52,117 \\
103,269 \\
249,758 \\
45,632 \\
532,437 \\
26,436 \\
486,562 \\
10,073 \\
9,366 \\
70,764 \\
4,150 \\
51,829 \\
11,270 \\
3,515\end{array}$ & $\begin{array}{r}678 \\
1,098 \\
1,081 \\
866 \\
1,221 \\
971 \\
309 \\
733 \\
262 \\
693 \\
1,150 \\
779 \\
1,173 \\
756 \\
763 \\
702\end{array}$ & $\begin{array}{r}671 \\
1,080 \\
1,081 \\
866 \\
1,180 \\
1,014 \\
310 \\
733 \\
262 \\
667 \\
1,263 \\
776 \\
1,173 \\
756 \\
735 \\
741\end{array}$ & $\begin{array}{l}43 \cdot 1 \\
55 \cdot 6 \\
7 \cdot 5 \\
16 \cdot 7 \\
70 \cdot 9 \\
91 \cdot 4 \\
16 \cdot 1 \\
14 \cdot 6 \\
6 \cdot 4 \\
66 \cdot 4 \\
94 \cdot 4 \\
14 \cdot 1 \\
12 \cdot 2 \\
6 \cdot 5 \\
32 \cdot 3 \\
74 \cdot 1\end{array}$ & $\begin{array}{l}47 \cdot 4 \\
32 \cdot 2 \\
92 \cdot 4 \\
81 \cdot 0 \\
10 \cdot 3 \\
4 \cdot 2 \\
81 \cdot 7 \\
85 \cdot 3 \\
91 \cdot 7 \\
19 \cdot 4 \\
3 \cdot 7 \\
78 \cdot 6 \\
87 \cdot 8 \\
92 \cdot 5 \\
25 \cdot 0 \\
24 \cdot 7\end{array}$ & $\begin{array}{c}2.9 \\
3 \cdot 9 \\
0 \cdot 5 \\
6 \cdot 3 \\
0 \cdot 4 \\
0 \cdot 2 \\
\\
\dagger \\
3 \cdot 6 \\
0 \cdot 4 \\
1 \cdot 3 \\
\\
\dagger \\
8 \cdot 3 \\
0.2\end{array}$ & $\begin{array}{r}6 \cdot 5 \\
8 \cdot 3 \\
0 \cdot 1 \\
1 \cdot 8 \\
12 \cdot 5 \\
4 \cdot 0 \\
2 \cdot 0 \\
0 \cdot 1 \\
1.9 \\
10 \cdot 6 \\
1 \cdot 5 \\
6 \cdot 0 \\
1 \cdot 0 \\
34 \cdot 4 \\
1.0\end{array}$ \\
\hline
\end{tabular}

* Source: Peninell Е H Mountin, J W and Pearson Kay “ Business Census of Hospitals, 1935." Washington: Government Printing Office, 1939. (Supplement No. 154 to Public Health Report.) Pages 22 and 27 (modified).

+ Less thain $0.05 \%$. 
TABLE XII

Sțate Distribution of Hospital Beds by Descending Order of Average State per Capita Income, 1935-37

\begin{tabular}{|c|c|c|c|c|c|c|c|c|}
\hline & & & & & \multicolumn{2}{|c|}{ General and Special } & \multirow{2}{*}{$\begin{array}{c}\text { Mental } \\
\text { (Beds per } 1,000 \\
\text { population) }\end{array}$} & \multirow{2}{*}{$\begin{array}{c}\text { Tuberculosis } \\
\text { (Beds per 1,000 } \\
\text { population) }\end{array}$} \\
\hline - & & & & & $\begin{array}{l}\text { Beds per } 1,000 \\
\text { populatior }\end{array}$ & $\begin{array}{l}\text { Patient days of } \\
\text { care per } 1,000 \\
\text { population }\end{array}$ & & \\
\hline United States & . & $\ldots$ & $\cdots$ & .. & $3 \cdot 14$ & $780 \cdot 0$ & $4 \cdot 12$ & $0 \cdot 55$ \\
\hline $\begin{array}{l}\text { First quarter } \\
\text { District of Colu } \\
\text { Delaware } \\
\text { New York } \\
\text { Nevada } \\
\text { California } \\
\text { Connecticut } \\
\text { Rhode Island } \\
\text { Massachusetts } \\
\text { Michigan } \\
\text { Maryland } \\
\text { Illinois } \\
\text { New Jersey } \\
\text { Wyoming }\end{array}$ & $\begin{array}{l}\ldots \\
\text { imbia } \\
\ldots \\
\ldots \\
\ldots \\
\ldots \\
\ldots \\
\cdots \\
\ldots \\
\ldots \\
\ldots \\
\cdots\end{array}$ & $\begin{array}{l}\cdots \\
\cdots \\
\cdots \\
\cdots \\
\cdots \\
\cdots \\
\cdots \\
\cdots \\
\cdots \\
\cdots \\
\cdots\end{array}$ & $\begin{array}{l}\cdots \\
\cdots \\
\cdots \\
\cdots \\
\cdots \\
\ldots \\
\cdots \\
\cdots \\
\cdots \\
\cdots \\
\cdots\end{array}$ & \begin{tabular}{l|}
$\cdots$ \\
$\cdots$ \\
$\cdots$ \\
$\cdots$ \\
$\cdots$ \\
$\cdots$ \\
$\cdots$ \\
$\cdots$ \\
$\cdots$ \\
$\cdots$ \\
$\cdots$ \\
$\cdots$ \\
$\cdots$
\end{tabular} & $\begin{array}{l}4 \cdot 16 \\
5 \cdot 34 \\
3 \cdot 10 \\
4 \cdot 58 \\
3 \cdot 23 \\
4 \cdot 42 \\
3 \cdot 62 \\
4 \cdot 44 \\
5 \cdot 23 \\
3 \cdot 54 \\
4 \cdot 09 \\
3 \cdot 53 \\
3 \cdot 42 \\
2 \cdot 86\end{array}$ & $\begin{array}{r}1,108 \cdot 7 \\
1,361 \cdot 0 \\
790 \cdot 1 \\
1,286 \cdot 1 \\
925 \cdot 1 \\
1,173 \cdot 1 \\
960 \cdot 6 \\
1,300 \cdot 8 \\
1,340 \cdot 8 \\
988 \cdot 5 \\
1,106 \cdot 3 \\
865 \cdot 1 \\
874 \cdot 0 \\
565 \cdot 4\end{array}$ & $\begin{array}{l}5 \cdot 45 \\
0 \cdot 91 \\
5 \cdot 96 \\
6 \cdot 87 \\
3 \cdot 29 \\
4 \cdot 69 \\
5 \cdot 42 \\
5 \cdot 01 \\
6 \cdot 40 \\
4 \cdot 31 \\
5 \cdot 02 \\
4 \cdot 61 \\
5 \cdot 09 \\
3 \cdot 89\end{array}$ & $\begin{array}{l}0 \cdot 78 \\
1 \cdot 11 \\
0 \cdot 86 \\
0 \cdot 80 \\
-\overline{0} \\
1 \cdot 72 \\
1 \cdot 11 \\
0 \cdot 99 \\
0 \cdot 83 \\
0 \cdot 74 \\
0 \cdot 50 \\
0 \cdot 91 \\
0 \cdot 14\end{array}$ \\
\hline $\begin{array}{l}\text { Second quarter } \\
\text { Montana } \\
\text { Ohio } \\
\text { Washington } \\
\text { Pennsylvania } \\
\text { Oregon } \\
\text { Wisconsin } \\
\text { Colorado } \\
\text { Arizona } \\
\text { Minnesota } \\
\text { New Hampshire } \\
\text { Maine } \\
\text { Indiana }\end{array}$ & $\begin{array}{l}\cdots \\
\cdots \\
\cdots \\
\cdots \\
\cdots \\
\cdots \\
\cdots \\
\cdots \\
\cdots \\
\cdots\end{array}$ & $\begin{array}{l}\cdots \\
\cdots \\
\cdots \\
\cdots \\
\cdots \\
\cdots \\
\cdots \\
\cdots \\
\cdots \\
\cdots \\
\cdots\end{array}$ & $\begin{array}{l}\cdots \\
\cdots \\
\cdots \\
\cdots \\
\cdots \\
\cdots \\
\cdots \\
\cdots \\
\cdots \\
\cdots\end{array}$ & \begin{tabular}{l|}
$\cdots$ \\
$\ldots$ \\
$\cdots$ \\
$\ldots$ \\
$\cdots$ \\
$\cdots$ \\
$\cdots$ \\
$\ldots$ \\
$\ldots$ \\
$\ldots$ \\
$\cdots$
\end{tabular} & $\begin{array}{l}3 \cdot 36 \\
4 \cdot 98 \\
2 \cdot 84 \\
3 \cdot 76 \\
3 \cdot 48 \\
3 \cdot 66 \\
3 \cdot 73 \\
4 \cdot 33 \\
3 \cdot 61 \\
4 \cdot 13 \\
4 \cdot 02 \\
3 \cdot 18 \\
2 \cdot 23\end{array}$ & $\begin{array}{r}824 \cdot 3 \\
1,067 \cdot 2 \\
735 \cdot 7 \\
870 \cdot 5 \\
883 \cdot 8 \\
915 \cdot 9 \\
858 \cdot 4 \\
974 \cdot 7 \\
777 \cdot 8 \\
993 \cdot 7 \\
947 \cdot 6 \\
763 \cdot 7 \\
533 \cdot 1\end{array}$ & $\begin{array}{l}4 \cdot 24 \\
3 \cdot 53 \\
4 \cdot 04 \\
4 \cdot 58 \\
4 \cdot 03 \\
4 \cdot 82 \\
5 \cdot 43 \\
4 \cdot 42 \\
2 \cdot 19 \\
5 \cdot 07 \\
5 \cdot 18 \\
4 \cdot 29 \\
3 \cdot 45\end{array}$ & $\begin{array}{l}0.57 \\
0.37 \\
0.49 \\
0.61 \\
0.42 \\
0.56 \\
0.73 \\
1.60 \\
1 \cdot 39 \\
0 \cdot 78 \\
0 \cdot 47 \\
0 \cdot 57 \\
0.44\end{array}$ \\
\hline $\begin{array}{l}\text { Third quarter } \\
\text { Florida } \\
\text { Utah } \\
\text { Idaho } \\
\text { Missouri } \\
\text { Vermont } \\
\text { Nebraska } \\
\text { Iowa } \\
\text { Kansas } \\
\text { New Mexico } \\
\text { West Virginia } \\
\text { Texas } \\
\text { Virginia }\end{array}$ & $\begin{array}{l}\cdots \\
\cdots \\
\cdots \\
\cdots \\
\cdots \\
\cdots \\
\cdots \\
\cdots \\
\cdots \\
\cdots \\
\cdots\end{array}$ & $\begin{array}{l}\cdots \\
\cdots \\
\cdots \\
\cdots \\
\cdots \\
\cdots \\
\cdots \\
\cdots \\
\cdots \\
\cdots \\
\cdots\end{array}$ & $\begin{array}{l}\cdots \\
\cdots \\
\cdots \\
\cdots \\
\cdots \\
\cdots \\
\cdots \\
\cdots \\
\cdots \\
\cdots\end{array}$ & \begin{tabular}{l|}
$\cdots$ \\
$\cdots$ \\
$\cdots$ \\
$\cdots$ \\
$\cdots$ \\
$\cdots$ \\
$\cdots$ \\
$\cdots$ \\
$\cdots$ \\
$\cdots$ \\
$\cdots$ \\
$\cdots$
\end{tabular} & $\begin{array}{l}2 \cdot 51 \\
2 \cdot 72 \\
3 \cdot 40 \\
2 \cdot 84 \\
2 \cdot 78 \\
3 \cdot 00 \\
3 \cdot 19 \\
2 \cdot 73 \\
2 \cdot 60 \\
3 \cdot 23 \\
2 \cdot 66 \\
1 \cdot 98 \\
2 \cdot 04\end{array}$ & $\begin{array}{l}550 \cdot 7 \\
514 \cdot 9 \\
804 \cdot 5 \\
576 \cdot 7 \\
683 \cdot 4 \\
734 \cdot 8 \\
718 \cdot 5 \\
598 \cdot 3 \\
570 \cdot 6 \\
554 \cdot 4 \\
566 \cdot 8 \\
394 \cdot 5 \\
499 \cdot 3\end{array}$ & $\begin{array}{l}3 \cdot 20 \\
2 \cdot 92 \\
2 \cdot 68 \\
2 \cdot 96 \\
3 \cdot 53 \\
5 \cdot 64 \\
3 \cdot 90 \\
4 \cdot 15 \\
3 \cdot 71 \\
2 \cdot 03 \\
2 \cdot 12 \\
2 \cdot 41 \\
3 \cdot 82\end{array}$ & $\begin{array}{l}0.36 \\
0.36 \\
- \\
0.50 \\
0.53 \\
0.12 \\
0.31 \\
0.23 \\
0.91 \\
0.41 \\
0.35 \\
0.45\end{array}$ \\
\hline $\begin{array}{l}\text { Fourth quarter } \\
\text { Louisiana } \\
\text { South Dakota } \\
\text { Oklahoma } \\
\text { North Dakota } \\
\text { Tennessee } \\
\text { Kentucky } \\
\text { Georgia } \\
\text { North Carolina } \\
\text { South Carolina } \\
\text { Alabama } \\
\text { Arkansas } \\
\text { Mississippi }\end{array}$ & $\begin{array}{l}\cdots \\
\cdots \\
\cdots \\
\cdots \\
\cdots \\
\cdots \\
\cdots \\
\cdots \\
\cdots \\
\cdots\end{array}$ & $\begin{array}{l}\cdots \\
\cdots \\
\cdots \\
\cdots \\
\cdots \\
\cdots \\
\cdots \\
\cdots \\
\cdots \\
\cdots \\
\cdots\end{array}$ & $\begin{array}{l}\cdots \\
\cdots \\
\cdots \\
\cdots \\
\cdots \\
\cdots \\
\cdots \\
\cdots \\
\cdots \\
\cdots \\
\cdots\end{array}$ & \begin{tabular}{l|}
$\cdots$ \\
$\cdots$ \\
$\cdots$ \\
$\cdots$ \\
$\cdots$ \\
$\cdots$ \\
$\cdots$ \\
$\cdots$ \\
$\cdots$ \\
$\cdots$ \\
$\cdots$
\end{tabular} & $\begin{array}{l}1 \cdot 72 \\
2 \cdot 63 \\
2 \cdot 63 \\
1.67 \\
3 \cdot 04 \\
1.67 \\
1 \cdot 69 \\
1 \cdot 55 \\
1 \cdot 86 \\
1 \cdot 60 \\
1 \cdot 39 \\
1 \cdot 26 \\
1 \cdot 26\end{array}$ & $\begin{array}{l}376 \cdot 9 \\
725 \cdot 0 \\
484 \cdot 2 \\
301 \cdot 4 \\
656 \cdot 1 \\
386 \cdot 6 \\
366 \cdot 0 \\
343 \cdot 5 \\
434 \cdot 9 \\
395 \cdot 4 \\
285 \cdot 3 \\
207 \cdot 6 \\
209 \cdot 7\end{array}$ & $\begin{array}{l}2 \cdot 56 \\
3 \cdot 46 \\
3 \cdot 45 \\
3 \cdot 24 \\
4 \cdot 35 \\
2 \cdot 43 \\
2 \cdot 41 \\
2 \cdot 48 \\
2 \cdot 18 \\
2 \cdot 58 \\
2 \cdot 09 \\
1 \cdot 96 \\
2 \cdot 22\end{array}$ & $\begin{array}{l}0.29 \\
0.15 \\
0.28 \\
0.32 \\
0.57 \\
0.37 \\
0.23 \\
0.19 \\
0.45 \\
0.31 \\
0.14 \\
0.35 \\
0.24\end{array}$ \\
\hline
\end{tabular}
Source: Pennell, E. H., Mountin, J. W., and Pearson, Kay. "Existence and Use of Hospital Facilities among the Several States
in Relation to Wealth as expressed by Per Capita Income." Publ. Hlth Rep., 55, 822, May 10, 1940. Hospitals operated by federal in Relation to Wealth as expressed by Per Capita Income." Publ. Hlth Rep., 55, 822, May 10, 1940. Hospitals operated by federal
agencies are not included. Special hospitals as used here are hospitals furnishing types of care which are closely identified with general medical and surgical care. (Modified.) 
TABLE XIII

Non-Federal Health Faculty Needs ${ }^{1}$

\begin{tabular}{|c|c|c|c|c|c|c|c|c|}
\hline \multirow{2}{*}{\multicolumn{5}{|c|}{ Type }} & \multirow{2}{*}{ Units needed } & \multirow{2}{*}{$\begin{array}{l}\text { Estimated unit } \\
\text { cost }\end{array}$} & \multicolumn{2}{|c|}{ Total estimated cost } \\
\hline & & & & & & & New & Replacement \\
\hline \multicolumn{2}{|c|}{$\begin{array}{l}\text { General Hospitals } \\
\text { New beds (deficit) } \\
\text { Replacement beds }\end{array}$} & $\cdots$ & $\ddot{x}$ & . & $\begin{array}{r}169,579^{2} \\
83,889^{7}\end{array}$ & $\begin{array}{r}\$ 6,000 \\
6,000\end{array}$ & $\$ 1,017,474,000$ & $\$ 503,334,000$ \\
\hline \multicolumn{2}{|c|}{$\begin{array}{l}\text { Tuberculosis Hospitals } \\
\text { New beds (deficit) } \\
\text { Replacement beds }\end{array}$} & $\begin{array}{l}. \cdot \\
. \cdot\end{array}$ & $\ddot{x}$ & $\begin{array}{l}\cdots \\
\cdots\end{array}$ & $\begin{array}{l}65,189^{3} \\
17,313^{7}\end{array}$ & $\begin{array}{l}5,000 \\
5,000\end{array}$ & $235,945,000$ & $86,565,000$ \\
\hline \multicolumn{2}{|c|}{$\begin{array}{l}\text { Mental Hospitals } \\
\text { New beds (deficit) } \\
\text { Replacement beds }\end{array}$} & $\begin{array}{l}. \\
\cdots\end{array}$ & $\begin{array}{l}\cdots \\
\cdots\end{array}$ & $\begin{array}{l}. \cdot \\
.\end{array}$ & $\begin{array}{r}208,963^{4} \\
99,583^{7}\end{array}$ & $\begin{array}{l}3,000 \\
3,000\end{array}$ & $626,889,000$ & $298,749,000$ \\
\hline \multicolumn{2}{|c|}{$\begin{array}{l}\text { Chronic Hospitals } \\
\text { New beds (deficit) } \\
\text { Public Health Centres }\end{array}$} & $\because$. & $\begin{array}{l}\ldots \\
\ldots\end{array}$ & 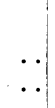 & $\begin{array}{r}270,173^{5} \\
4,503^{6}\end{array}$ & $\begin{array}{r}3,000 \\
60,000\end{array}$ & $\begin{array}{l}810,519,000 \\
270,180,000\end{array}$ & \\
\hline \multirow[t]{2}{*}{ Total cost } & \multicolumn{2}{|c|}{$\begin{array}{l}\text { New (deficit) } \\
\text { Replacement }\end{array}$} & $\begin{array}{l}. . \\
\cdots\end{array}$ & $\begin{array}{l}. . \\
.\end{array}$ & & & $\$ 3,051,007,000$ & $\$ 888,648,000$ \\
\hline & Both & . & .. & .. & & & \multicolumn{2}{|c|}{$\$ 3,939,655,000$} \\
\hline
\end{tabular}

1 Includes the 48 States, District of Columbia, Alaska, Hawaii, and Puerto Rico.

2 On the basis of 4.5 beds per thousand 1940 State population and after deducting existing general and allied special beds listed in the 1948 Hospital Number of the Journal of the American Medical Association.

On the basis of 2.5 beds per tuberculosis death as applied to the average annual number of such deaths in each State during the three-year period 1941-43 and after deducting existing tuberculosis beds listed in the 1945 Hospital Number of the Journal of the American Medical Association (with the 1942 Directory of the National Tuberculosis Association used as a check).

4 On the basis of 5 beds per thousand 1940 State population and after deducting existing mental and nervous and mental beds listed in the 1945 Hospital Number of the Journal of the American Medical Association.

5 On the basis of 2 beds per thousand State population estimated by the U.S. Census Bureau as of July 1 , 1944. Since no deductions were made here for existing beds, this is a gross need figure, balanced to some extent by the deduction of existing allied special beds from the gross need figures for general beds. See footnote 8 .

6 On the basis of one public health centre per 30,000 State population estimated by the U.S. Census Bureau as of July 1 , 1944 , with no deductions made for the relatively few existing adequate public health centres.

7 Based on the assumption that 25 per cent. of existing facilities in each State need to be replaced, with that 25 per cent. reduced by any excess in existing facilities over the standard ratios.

Source: Testimony of the Surgeon General, U.S. Public Health Service, before the Public Health Sub-committee of the House Committee on Interstate and Foreign Commerce. March 7, 1946, on S. 191.

Certain of the limitations of the Act are implicit in the points listed above which have ensured its widespread support. In particular, it avoids the controversial issue of staffing, and as Hoge has pointed out (1947) it is those areas most deficient in both facilities and staff in which the provision of either separately will do least to ensure an adequate number of operating units. Moreover, the mechanism of matched grants, though based on the reasonable wish to guarantee local participation in Federal-sponsored developments, inevitably imposes a handicap on the poorer States. Finally, even if full use is made of all the money provided by the Act $(\$ 1,125,000,000$ with the appropriate State contribution), it will meet only about 30 per cent. of the estimated cost of requirements $(\$ 3,939,655,000$ (see Table XIII)). In spite of these limitations, however, the Act will make a considerable contribution to hospital development, and establishes firmly the role of the Federal Government in this important facet of medical care.

At the present time (April, 1948) 47 States have appointed planning agencies. Plans for construction presented by 27 States have been approved, and the funds allotted total $\$ 45,703,650$. Applications to the Division of Hospital Facilities of the United States Public Health Service have been received from 11 States for ninety-two specific hospital projects; of these, two have had final approval, and ninety have been approved in part.

\section{VOLUNTARY HEALTH INSURANCE}

\section{INTRODUCTION}

In the absence of any government-operated system of curative services, financed by compulsory insurance or by taxation, there has inevitably been 
a considerable demand for voluntary health insurance. It has been met by a rapid expansion of profit and non-profit plans. While there has been some controversy on the scope and implications of this insurance, it has in general been well received by people who recognize the inadequacy of medical services financed exclusively by private fees, yet who for one reason or another deplore the possibility of a truly comprehensive service which would bring the government, Federal or State or both, wholeheartedly into the curative field. On these grounds it has been supported by American doctors, and more than four-fifths of the physicians in private practice now participate in voluntary insurance schemes (Scott, 1947).

It is estimated that of a population of 147 million Americans, roughly 100 millions can afford the actuarial costs of some form of health insurance (Scott, 1947); there are about 91 million members of the more important voluntary schemes (Table XIV). Such figures cannot be taken to indicate

TABLE XIV

Membership of Voluntary Insurance Plans

\begin{tabular}{|c|c|c|c|}
\hline Plan & Covers & Benefit & $\begin{array}{l}\text { Approximate } \\
\text { membership }\end{array}$ \\
\hline $\begin{array}{l}\text { Medical } \\
\text { Co-op- } \\
\text { eratives } \\
\text { Industrial } \\
\text { and } \\
\text { Labour } \\
\text { Union } \\
\text { Govern- } \\
\text { ment and } \\
\text { Univer- } \\
\text { sity }\end{array}$ & $\begin{array}{l}\text { Hospital charges } \\
\text { Medical services } \\
\text { Medical services } \\
\text { (chiefly) } \\
\text { Accident and sick- } \\
\text { ness benefit } \\
\text { Accidental death } \\
\text { and dismember- } \\
\text { ment benefit } \\
\text { Hospital charges } \\
\text { Medical services } \\
\text { Mod }\end{array}$ & $\begin{array}{l}\text { Service } \\
\text { Service } \\
\text { Service } \\
\text { or cash } \\
\text { Cash } \\
\text { Cash } \\
\text { Cash } \\
\text { Cash }\end{array}$ & $\begin{array}{l}30,000,00 \mathrm{C} \\
\text { (Jan., 1948) } \\
7,250,000 \\
\text { (Jan., 1948) } \\
\text { 6,500,000 } \\
\text { (Sept., 1947) } \\
\text { ) } \\
44,000,000 \\
\text { (July, 1947) }\end{array}$ \\
\hline
\end{tabular}

Population of the United States, $1947=143,414,000$.

that nine-tenths of the eligible public are already reached by voluntary health insurance, much less that nine-tenths are protected against the full costs of medical care. Few plans cover the costs of all medical services, and some people are members of more than one plan. Recent estimates give the following figures for different classes of benefit
(American Medical Association, Council on Medical Service, 1948b):

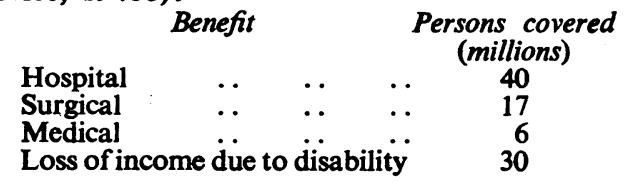

It would be ungenerous to deny the considerable success which voluntary plans have achieved; it would be inaccurate to overlook their conspicuous deficiencies. They provide only for that section of the population whose income will meet the costs of regular contributions, and whose providence requires no support from a compulsory clause. The service offered is almost invariably limited to some feature of medical benefit, and few members are protected against all medical costs. Finally, voluntary health insurance does nothing to promote the unity of preventive and curative services.

The correction of these features is impeded in the United States by the fact that the States impose independently the conditions under which non-profit insurance plans operate. Most States have passed enabling legislation bringing them under the general corporation laws relating to non-profit corporations. They are classed as a special type of insurance under the supervision and control of the State Departments of Insurance, and are thus "freed from the obligation of maintaining the high reserves required of commercial insurance companies, and relieved of paying taxes" (Sinai, Anderson, and Dollar, 1946a).

\section{Blue Cross and Blue Shield Plans}

Non-profit hospital prepayment plans were introduced in 1933 when the American Hospitals Association gave its support to the principle of voluntary insurance against the costs of hospital care. This insurance is operated by corporations established independently in the States, and controlled by Boards of Trustees consisting of members of the medical profession and of the hospitals. It covers chiefly groups of employed persons (and may include their dependants) who contribute by a regular wage deduction: Though such constitute 95 per cent. of the membership, an attempt has recently been made to extend the insurance to self-employed persons, and to those living in rural areas (Corwin, 1946). Sinai, Anderson, and Dollar (1946b) give the following figures for 1943:

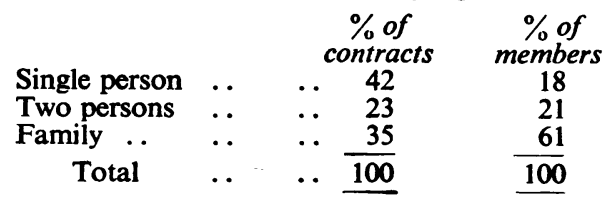


The corporations contract with hospitals, which undertake to provide the requisite service, described by Rorem (1945) as follows: "Typically they furnish complete hospital care for three or four weeks per illness per year, with discount periods of from ninety days to six months following the full coverage period. Benefits usually include all services available through the member hospital, that is the items which appear on the bill presented or payable by a patient. Most plans now cover all types of illness, except those for which a subscriber receives service by virtue of some Federal or State law" (for example, mental illness, tuberculosis, and infectious disease). Neither surgical nor medical fees are included, and these must be paid privately by the patient or covered by a separate insurance contract for which in the past Blue Cross made no provision.

Unfortunately a difficulty is inherent in the feature which distinguishes Blue Cross from commercial insurance. The provision of service in place of cash benefit protects the patient against variable hospital costs, but exposes the corporation to the risk that its charges may not be commensurate with its commitments. When prices are rising rapidly such adjustments are not easily made, and many corporations now face a choice between increased charges or reduced benefits, which may eventually force a return to the less attractive cash benefit.

Blue Cross membership has increased rapidly from 2,000 in 1933 to over 30 million in October, 1947 (Table XV). One or more plans are operated in every State, and cover for limited benefit about 20 per cent. of the population.

The conspicuous omission of provision for the costs of medical and surgical service has led to a more recent insurance plan known as Blue Shield. Operated on the same principles as Blue Cross, it insures members against the costs of medical

TABLE XV

Growth of Non-Profit Hospital Service Plans*

\begin{tabular}{c|c|c}
\hline Year & Number of plans & $\begin{array}{c}\text { Enrolment } \\
\text { (round numbers) }\end{array}$ \\
\hline 1933 & 1 & 2,000 \\
1935 & 10 & 54,000 \\
1937 & 26 & 608,000 \\
1939 & 65 & $2,870,000$ \\
1941 & 73 & $6,049,200$ \\
1943 & 77 & $10,458,900$ \\
1945 & 85 & $16,500,000$ \\
1947 & 88 & $28,800,000$ \\
1948 & 88 & $30,000,000$ \\
\hline
\end{tabular}

* Source: Rorem, Rufus C. "Blue Cross Hospital Service Plans." 2nd edition. Chicago. American Hospitals Association, 1944, page 6. (Modified.) services. Membership in January, 1948, was 7,250,000 (Table XIV).

These two schemes, which in the past have been separately administered, provide complementary services and are at present being co-ordinated nationally. The intention is to offer a uniform insurance plan which includes both hospital and medical costs.

\section{Medical Society Plans}

The medical profession opposes compulsory health insurance, but in recent years has given its blessing to voluntary insurance on the following terms (American Medical Association, 1934):

(a) Medical sponsorship and control of all medical service plans.

(b) Separate administration of hospital and medical plans.

(c) Cost of medical service to be determined by the income of the patient.

(d) Medical benefits and disability benefits to be under separate administration.

The American Medical Association later (1938) stipulated that benefits should be paid in cash directly to the individual member, but, since some State societies have provided service and not cash benefits, the reservation was withdrawn.

Since 1939 State medical societies have sponsored voluntary health insurance schemes which on September 30, 1946, had six and a half million members (Table XIV). These schemes are operated (like Blue Cross) by non-profit corporations, controlled by Boards of Trustees of which membership is predominantly or exclusively medical. The plans are available to groups of workers and their dependants, and contributions are collected by regular wage deductions. The basis of eligibility varies from State to State, and may admit:

(1) persons whose incomes are below a fixed limit (usually $\$ 1,800-\$ 2,000$ a year for single individuals, and $\$ 2,400-\$ 3,000$ a year for families), or (2) all persons who can afford the contributions, or (3) all persons who can afford the contributions, on the understanding that members whose incomes are above a limit may be charged additional fees.

Since plans are developed independently by State medical societies, it is not surprising that they differ from one State to another. The benefits offered are usually in service rather than in cash, and while some provide a fairly comprehensive service (for example the California Physicians' Service), others are limited to surgical and obstetric care. Mental illness, tuberculosis, self-inflicted injury, and illness covered by the compensation laws, are excluded. Doctors who participate in the scheme continue in private practice, and are paid by fees for services to insured persons. 
There can be little doubt that as at present constituted medical society plans are not so much an attempt to solve a problem as to forestall an alternative solution. The fear of the introduction of compulsory health insurance by the Government, or of a considerable extension of voluntary insurance under lay control, has undoubtedly stimulated the medical profession to face what it conceives to be its own problems. It is hardly surprising in these circumstances that the solution is inadequate, and recognizing the need for more unified control the American Medical Association in 1946 created a single agency for the development of a national system of voluntary insurance, to be operated by the local medical societies. Approval is given to plans which conform to the requisite standards.

\section{Commercial Accident and Health Insurance}

The commercial insurance companies, which for many years have offered insurance against loss of income from sickness and accident, now write policies which protect against the costs of hospitalization, and of surgical and medical care. This insurance is available to individuals or to groups, and in the case of insured workers may include dependants. The commercial companies make no contract with either hospitals or physicians, and benefits, unlike those of Blue Cross and Blue Shield, are paid in cash and not in service, a fact which contributes more to the solvency of the companies than to the needs of the insured population. In July, 1947, there were 44 million commercial policies (Table XIV).

\section{Other Plans}

There are a number of other voluntary health insurance plans, which have a small membership (Table XIV) but are of interest because of the nature of their organizations. They include:

(a) Medical Co-operatives: A form of insurance owned and operated by the enrolled members. A survey by the American Medical Association reported that in 1947 there were 92 such plans in 31 States. The largest had 60,000 members, and the total membership of all plans was about 750,000 (Ryan, 1947). They have recently united nationally under the Co-operative Health Federation of America.

The Co-operatives commonly employ salaried doctors, some of whom practice in groups. The service offered is fairly comprehensive, and has been of particular value in rural areas not reached by alternative services. None the less this form of health insurance has not had the support of the American Medical Association, which objects on principle to developments in which control is not exercised by the medical profession. (b) Industrial and Labour Union: Only a few industrial establishments accept responsibility for the general medical services for their workers; fewer still provide for dependants. Where they exist such services may be financed by the employer, or by voluntary insurance. Only the latter are referred to in this context. They vary greatly in respect of services offered, and of arrangements with medical staff. In a few cases labour unions provide medical services for union members.

\section{GROUP PRACTICE}

\section{INTRODUCTION}

American group practice is essentially an association of doctors whose activities are confined to curative practice, financed as a rule on the fee for service principle. It developed rapidly after the first world war, when doctors who had served in the forces were impressed with the possibilities of more highly organized practice, and felt a need for some form of co-operation in those communities where medical services were in a primitive state (The Bureau of Medical Economics, 1933). The fact that it has developed within the framework of private medicine and in competition with doctors working independently has resulted in controversy which is by no means confined to comment on its technical merits, and which is further confused by the supposed association between group insurance and group practice which has led critics who feared the one to condemn the other. Only a small proportion of groups are financed by prepayment plans (Hunt and Goldstein, 1947b), an arrangement which may facilitate their operation, but cannot be considered essential to it.

For information on American group practice there are three main sources to which we may turn:

1. Comprehensive surveys made by the Bureau of Medical Economics (1933, 1941) and by the United States Public Health Selvice (Hunt, 1947; Hunt and Goldstein, 1947b). They are the only sources representative of all or of nearly all groups.

2. Detailed examinations of a limited number of selected groups (Rorem, 1931; Clark and Clark, 1941; Goldmann, 1941: Hunt and Goldstein, 1947a).

3. An extensive series of personal opinions and impressions of group practice, supported as a rule by little objective evidence.

The fact that groups vary in respect of the number of member physicians, in the nature of their collaboration, and in services provided, has made it necessary to define empirically the basis of inclusion. Many definitions have been suggested (Rorem, 1931; Bureau of Medical Economics, 1933; Clark and Clark, 1941; Moore, 1943; Goldmann, 1946; 
Hunt, 1947). Hunt excludes "groups with fewer than three full-time physicians, groups practising a single specialty, organized hospital staffs where the physicians participate on a part-time voluntary basis, and informal groups in which members share overheads but carry on medical practice as individuals." This definition " permits the inclusion of groups of physicians employed by industrial companies, hospitals, consumer co-operatives or individual owners, as long as the physicians carry on their principal professional activity by working together as a group."

The discussion which follows is based chiefly on Hunt's study, which is the most recent and comprehensive (Hunt, 1947; Hunt and Goldstein, 1947b). In 1946 he sent questionnaires to all listed groups (981). Of these, 774 (78.9 per cent.) sent replies, of which 368 conform to the definition given above. The confusion between the grouping of patients and the grouping of doctors is evident in the inclusion of 75 prepayment plans unrelated to group practice in the original list, from which returns were classified as follows:

1. Medical groups conforming to the definition ....$\quad \ldots$..

2. Groups with 3 or more full-time physicians, but practising a single specialty $\ldots$.. $\quad$.. .

3. Groups with fewer than 3 full-time physician members

4. Pre-payment plans with no group practice by the participating physicians .. $\quad$. $\quad$.. $\ldots$

5. Groups with no formal organization for the practice of medicine ...

6. Former groups which have disbanded $\ldots$..

7. Groups with 3 or more full-time physicians which gave no other information and consequently had to be excluded from the tabulations $\cdots \quad \cdots \quad \ldots$

8. Questionnaires returned by post office, addressee unknown

Number of returns

368

Total

$$
\text { .. }
$$

\section{Organization}

In 1941 the Bureau of Medical Economics reported that less than 2 per cent. of American doctors were wholly engaged in group practice. The 368 groups included by Hunt were staffed by 3,084 doctors (again rather less than 2 per cent.) and the total is not greatly increased by inclusion of the part-time physicians employed by 93 groups (Table XVI). Most groups were quite small, and more than half had fewer than six member physicians. There were,

TABLE XVI

Group SizE*

\begin{tabular}{c|c|c|c|c}
\hline $\begin{array}{c}\text { No. of } \\
\text { full-time } \\
\text { physicians }\end{array}$ & $\begin{array}{c}\text { No. of } \\
\text { groups }\end{array}$ & $\begin{array}{c}\text { Percentage } \\
\text { of groups }\end{array}$ & $\begin{array}{c}\text { No. of } \\
\text { of } \\
\text { physicians } \\
\text { in groups }\end{array}$ & $\begin{array}{c}\text { Percentage } \\
\text { of } \\
\text { physicians } \\
\text { in groups }\end{array}$ \\
\hline 3 & 82 & $22 \cdot 3$ & 246 & $8 \cdot 0$ \\
4 & 74 & $20 \cdot 1$ & 296 & $9 \cdot 6$ \\
5 & 38 & $10 \cdot 3$ & 190 & $6 \cdot 2$ \\
6 & 35 & $9 \cdot 5$ & 210 & $6 \cdot 8$ \\
7 & 16 & $4 \cdot 3$ & 112 & $3 \cdot 6$ \\
8 & 22 & $6 \cdot 0$ & 176 & $5 \cdot 7$ \\
9 & 14 & $3 \cdot 8$ & 126 & $4 \cdot 1$ \\
10 & 14 & $3 \cdot 8$ & 140 & $4 \cdot 5$ \\
$11-15$ & 42 & $11 \cdot 4$ & 536 & $17 \cdot 4$ \\
$16-20$ & 16 & $4 \cdot 4$ & 284 & $9 \cdot 2$ \\
\hline 21 and & 15 & $4 \cdot 1$ & 768 & $24 \cdot 9$ \\
\hline over & 15 & 100 & 3.084 & 100 \\
\hline & 368 & & & \\
\hline
\end{tabular}

- Source: Hunt, G. Halsey, and Goldstein, Marcus S. J. Amer. med. Ass., 135, 904 (1947).

t Includes a few very large groups.

however, a few large groups, which accounts for the fact that about a quarter of the physicians engaged in group practice worked in groups with more than twenty members.

The numbers of groups operated under various types of organization are shown in Table XVII. About 77 per cent. were either partnerships of doctors, or partnerships which also employ other doctors, and another 10 per cent. were owned by a single doctor who employed his colleagues. Most of the remainder were controlled by a single sponsoring organization, or by a corporation.

\section{Services Provided}

Only 15 per cent. of groups were financed by prepayment plans (Hunt and Goldstein, 1947b), and it is therefore unusual for them to offer preventive as well as curative services. The work of most groups is comparable to that of the general practitioner or consultant in curative practice, and is concerned principally with office and domiciliary care. Of 368 groups questioned by Hunt, 117 (31.8 per cent.) stated that they had their own hospital, though whether the hospitals were owned by all these groups was not made clear. The definition given above includes hospitals staffed by full-time physicians, and for such groups in-patient service is an intrinsic part of the work.

Hunt distinguishes between service and reference groups as follows:

1. Service groups: "Those whose principal activity is the furnishing of complete medical care to a continuing clientele." 
2. Reference groups: "Those whose principal activity is the furnishing of specialized care to patients referred to them by outside physicians, usually for a single episode of illness, and that ordinarily do not undertake to furnish complete medical care to a continuing clientele."

Of 361 groups, 342 were classified as service, and 19 as reference groups (Table XVIII). More than 80 per cent. included surgery, medicine, obstetrics, radiology, and gynaecology in services offered; less than 25 per cent. included dentistry. Though of interest, such figures throw little light on the optimum ratio of specialties which should be grouped in association with each other. A few groups have attempted to provide a medical service for a whole community, but most have been located and staffed with no such objective, and their services reflect opportunities in competitive practice and the interests of the staff, rather than a planned development.

Critics have questioned the quality of the specialist services which groups undertake to provide, and the credentials of doctors offered by groups as specialists. The Bureau of Medical Economics (1941) reported that of 2,093 doctors in full-time group service, only 395 (19 per cent.) were labelled as general practitioners; of 1,698 described as specialists 507 were accredited by specialty boards, 387 were members of specialist societies, and 804 offered no evidence to support their claims to specialist status (Table XIX).

These facts throw light on the fate of the general practitioner in service groups staffed mainly or completely by specialists. Some groups have replaced him, in the sense that each patient is seen by the appropriate specialist, an arrangement which has led to criticism of the more impersonal if

TABLE XVII

Group ORganization*

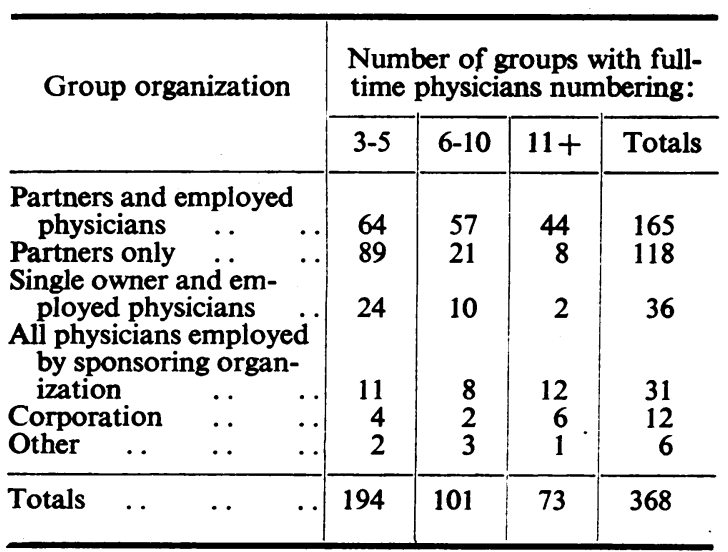

* Source: Hunt, G. Halsey, and Goldstein, Marcus S. J. Amer. med. Ass., 135, 904 (1947) (slightly modified).
TABLE XVIII

SERVICES PROVIDED BY 361 GROUPS*

\begin{tabular}{|c|c|c|c|c|c|}
\hline \multirow{2}{*}{\multicolumn{3}{|c|}{ Service }} & \multicolumn{3}{|c|}{ Number of groups } \\
\hline & & & Service & Reference & Total \\
\hline $\begin{array}{l}\text { Surgery .. } \\
\text { Medicine } \\
\text { Obstetrics } \\
\text { Radiology } \\
\text { Gynaecology } \\
\text { Paediatrics } \\
\text { Otolaryngology } \\
\text { Ophthalmology } \\
\text { Dentistry }\end{array}$ & $\begin{array}{l}\ldots \\
\cdots \\
\cdots \\
\cdots \\
\cdots \\
\\
\end{array}$ & $\begin{array}{l}\cdots \\
\cdots \\
\cdots \\
\cdots \\
\cdots \\
\cdots \\
\cdots \\
\cdots\end{array}$ & $\begin{array}{r}342 \\
340 \\
312 \\
306 \\
300 \\
265 \\
212 \\
194 \\
82\end{array}$ & $\begin{array}{r}18 \\
16 \\
9 \\
15 \\
12 \\
7 \\
12 \\
11 \\
6\end{array}$ & $\begin{array}{r}360 \\
356 \\
321 \\
321 \\
312 \\
272 \\
224 \\
205 \\
88\end{array}$ \\
\hline
\end{tabular}

* Source: Hunt, G. Halsey, and Goldstein, Marcus S. J. Amer. med. Ass., 135, 904 (1947) (slightly modified).

more expert service which has resulted. But in other groups the change has been one of title rather than of function, and though attended nominally by a specialist (usually in internal medicine) patients are in fact served by a personal physician.

\section{Advantages and Disadvantages}

There are three main advantages which, without reference to experience, it seems reasonable to attribute to the organization of doctors in groups:

1. It may assist the integration of preventive and curative services.

2. It may effect economies in the use of medical manpower, and facilitate access to specialist opinion and services.

3. It may make more efficient use of facilities and of supplementary staff.

Most other advantages which have been listed (for example, more regular hours of work, improved opportunities for study or for holidays, higher incomes, etc.) are derived from these three, or are concerned with the questions of competition and of income rather than of service.

American evidence on the first point is inconclusive. A small number of groups financed by insurance accept responsibility for the health of the insured population, and some of them provide excellent preventive and curative services which undoubtedly benefit from unified responsibility and control (for example, the Permanente Plan; Garfield, 1944). With these few exceptions American group practice has not realized the integrated service which has been discussed in relation to health centres in Great Britain.

It would require an elaborate medical accountancy to enable us to assess the relative efficiency of group and of private practice. Common sense may suggest that it is more efficient for several doctors 
TABLE XIX

\begin{tabular}{|c|c|c|c|c|}
\hline ClassSIFICATION & BY SPEC & IALISTS n & $\mathrm{N} \quad 335 \quad \mathrm{G}$ & OUPS* \\
\hline Type of practice & $\begin{array}{c}\text { Accredi- } \\
\text { ted }\end{array}$ & $\begin{array}{l}\text { Member } \\
\text { of } \\
\text { Society }\end{array}$ & Reported & Total \\
\hline urgery & 79 & 205 & 167 & 451 \\
\hline $\begin{array}{l}\text { ternal medicine } \\
\text { phthalmology, } \\
\text { otology, laryn- } \\
\text { gology, rhino- }\end{array}$ & 110 & 57 & 229 & 396 \\
\hline logy & 122 & 23 & 102 & 247 \\
\hline $\begin{array}{ll}\text { gynaecology } & \ldots \\
\text { ediatrics } & .\end{array}$ & $\begin{array}{l}25 \\
34\end{array}$ & $\begin{array}{r}31 \\
9\end{array}$ & $\begin{array}{r}109 \\
52\end{array}$ & $\begin{array}{r}165 \\
95\end{array}$ \\
\hline $\begin{array}{l}\text { Jology } \\
\text { oentgenology }\end{array}$ & 29 & 17 & 47 & 93 \\
\hline $\begin{array}{l}\text { and radiology.. } \\
\text { orthopaedics }\end{array}$ & $\begin{array}{l}54 \\
20\end{array}$ & $\begin{array}{r}9 \\
11\end{array}$ & $\begin{array}{l}24 \\
21\end{array}$ & $\begin{array}{l}87 \\
52\end{array}$ \\
\hline psychiatry & 6 & 15 & 15 & 36 \\
\hline ermatology & 9 & 4 & 19 & 32 \\
\hline athology & 16 & 3 & 5 & 24 \\
\hline naesthesia & 3 & 3 & 6 & 12 \\
\hline roctology & - & - & 5 & 5 \\
\hline hysical therapy & - & - & 2 & 2 \\
\hline uberculosis $\quad$. & - & - & 1 & 1 \\
\hline Jeneral practice & 507 & 387 & $\begin{array}{l}804 \\
395\end{array}$ & $\begin{array}{r}1,698 \\
395\end{array}$ \\
\hline $\begin{array}{l}\text { otal physicians } \\
\text { in groups }\end{array}$ & & & & 2,093 \\
\hline
\end{tabular}

* Source: J. Amer. med. Ass., 117, 123, Organization Section, Group Practice (1941).

to share facilities and supplementary staff, but it is quite another matter to prove it. No satisfactory objective comparisons can be made, and we are left to make what we can of numerous opinions which are about equally divided on this matter (Hunt, 1947). It is usually agreed that patients are more readily (sometimes too readily) referred for specialist opinion, but critics deplore the fact that such reference is limited to the members of a group whose credentials in some cases they are disposed to question.

There have been many criticisms of group organization, of which the following from the minority of the Committee on the Costs of Medical Care (1932) are typical:

" 1 . It would establish a medical hierarchy in every community to dictate who might practice there. This is inherent in the plan, since any new member of the centre must be chosen either by the chief or by a small staff.

" 2. It would be impossible to prevent competition among the many such centres necessary for large cities; cost would inevitably be increased by the organization necessary to assign patients to the various centres. This would add to the evils of medical dictatorship those of a new bureau in the local government with its attendant cost.
“ 3. Continuous personal relationship of physician and patient would be difficult if not impossible under such conditions.',

The first two points are concerned with competitive practice; the third merits examination, though it is worth observing that much more has always been made of the delicacy of this relationship by the physician than by the patient. According to Hunt (1947), " advocates of group practice are somewhat divided regarding the desirability of a "personal physician' for each patient, but they all agree that such a relation can be maintained in group practice as easily as in individual practice." Clark and Clark (1941) describe experience in a series of fifteen groups as follows: "As the public becomes more accustomed to group practice the choice among the members of the group is becoming less important. More and more patients now come to a clinic because they have confidence in the organization as a whole, and are usually little concerned about seeing any particular physician on the staff." While undoubtedly some patients and many doctors still prefer each patient to have a personal physician, there is little in American experience to suggest that the resulting relationship between doctor and patient is a serious barrier to the organization of group practice.

A more serious criticism made by the Bureau of Medical Economics (1941) is based on a study in North Carolina of 1,000 consecutive patients coming under the care of general practitioners. Of these, 848 are said to have required no treatment beyond the resources of the general practitioner. The results of the United States Public Health Service survey of the incidence of illness in 9,000 families are also quoted, showing that 72 per cent. of 32,752 cases of illness in a general population were uncomplicated, and could reasonably be considered within the competence of the average doctor. Consequently it is argued that an arrangement which makes specialist attention available is in most cases quite unnecessary.

One may accept these facts without subscribing to the conclusion based on them. Two considerations are pertinent to this issue. The first is that many diseases (for example rheumatic fever, tuberculosis, cancer) by no means invariably declare themselves in a form which brings the patient to medical attention at an early date, a fact to which the variability of symptoms and of individual response to discomfort both contribute. The second is that the practitioner who is without the support of specialist facilities may fail to recognize the seriousness of the condition with which he is dealing. Both points have been underlined by the results in one major disease in which we can now 
speak with some assurance for the whole population, that is, tuberculosis. The Medical Research Council investigators (Clark and others, 1945) reported that of 78 " treatment " cases discovered by mass radiography, 29 had no symptoms; of 49 which had symptoms, 32 had not been seen by a doctor, and 17 had been seen without recognition of the disease. (Four of these had also been referred to a specialist.) This argument for group practice rests, not on the claim that most cases require specialist care, but on the observation that many cases present with (or without) signs and symptoms which make them indistinguishable before investigation from the minority which do.

It would be unrealistic to suggest that group organization is a complete answer to this problem. Without more precise knowledge of the mechanism by which cases are brought to medical attention, and of the basis of reference to specialists, we cannot speak with confidence. The routine examination of susceptible groups may be quite as important as the consideration of patients complaining of symptoms. But if the questions of medical competition and finance are ignored (and in the United States at the present time they hardly can be), the ready access to specialist opinion and services which group practice facilitates is a legitimate argument in its favour.

There can be little doubt that under favourable circumstances group practice will commend itself to medical opinion. A questionnaire survey of 2,000 doctors in 1937 found a slight majority in favour of it (Lueth, 1945), and in 1944 the American Medical Association questioned doctors in the armed forces, of whom 52 per cent. indicated that they wished to practice in groups after the war. While replies were no doubt influenced by the cost of financing independent practice, it is probable that as in the 1914-18 war many younger doctors were favourably impressed by the advantages of group organization.

\section{DISCUSSION}

Few Americans who have considered the matter would question to-day that their medical services are in many respects seriously deficient, a unanimity attributable largely to three major investigations into the incidence of illness and the distribution of medical care (Sydenstricker, 1926; Falk, Klem, and Sinai, 1933; National Health Survey, 1945). At least 25 per cent. of counties are without adequate basic public health services (Mustard, 1945d); 40 per cent. have no registered hospitals (Parran, 1947); medical personnel are unevenly distributed (Parran, 1947); and the costs of medical care are quite beyond the means of many people who are either not covered or are inadequately covered by voluntary insurance. That similar deficiencies exist elsewhere is no defence in a country which is justifiably proud of its technical achievements in medicine, and cannot dismiss its responsibilities on the grounds of penury.

Unhappily the unanimity about the existence of the problem does not extend to its solution. The formal public health services are generally accepted as the responsibility of the central government, but there is no corresponding agreement about the administration of the curative services. Controversy centres on three proposals, which are not in fact quite distinct, but may conveniently be discussed separately:

1. The curative services are, with minor exceptions, the concern of the medical profession, and not of either the central or State governments.

2. The curative services of the whole country are the responsibility of the Federal Government.

3. The curative services are the separate responsibility of each State.

The first is the view of the American Medical Association (1934) and there is reason to believe that it corresponds with that of most doctors. Stated in more detail it is as follows:

(a) The Federal Government should confine its activities to the orthodox public health services, to the care of the indigent, and to the provision of funds to build hospitals, public health centres, etc.

(b) All other aspects of medical care should be under the control of the medical profession.

(c) Only the medical services of the lower income groups should be financed by pre-payment plans, and these should be voluntary in character.

(d) All other persons in the community should seek and pay for their own medical attention.

The objection to compulsory health insurance, and to voluntary health insurance not limited to the lower income groups, derives in part from a common misconception about the financial resources of patients. The fact is that the population cannot be divided into one section unable to pay for medical attention, for which the government must provide, and another able to meet the costs in full, which can be left to its own resources. The growth of health insurance indicates that many people whose incomes fluctuate through accident, illness, unemployment, or improvidence, are unable to bear the full cost in times of illness, but can make a contribution under an insurance scheme. To argue that those who will do so only under compulsion are not entitled to benefits which they have neglected to secure, is to ignore an attribute of human nature 
with which any effective administration must reckon.

A realistic examination of this problem results in the recognition of at least four groups, identified in respect of their ability to pay for medical care:

\section{Persons who can make no contribution.}

II. Persons who can make only a partial contribution under an insurance scheme.

III. Persons who can make a sufficient contribution under an insurance scheme, but who are otherwise unable to meet the costs of illness in full.

IV. Persons who can meet the costs of illness in full.

Medical services can be provided for groups I and II only if supported wholly or in part by government funds (that is, by taxation). Medical services for group III can be financed by an insurance scheme, but are unlikely to be adequate unless the scheme is compulsory in character. Only group IV can afford to pay privately the costs of illness in full, the plan favoured by the American Medical Association for most patients. It is clear that in addition to other relevant considerations the acceptability of such a plan must rest on an estimate of the size of the group. The view that it includes the greater part of the population cannot be squared with experience in other countries, nor, in the opinion of many observers, with the realities of the situation in the United States.

Federal responsibility for medical care is at present strictly limited, and any question of its extension sharply divides both medical and lay opinion. There is agreement about the Indians and the indigent, and about little else. The Hospital Survey and Construction Act of 1946 is an apparent exception, which extends Federal effort in the curative field, but for reasons already discussed this legislation is without much significance as a precedent. The chief point at issue is whether the Federal Government shall impose a system of compulsory health insurance on the whole country, a suggestion which unites in opposition the advocates of State and the advocates of medical control.

Considerations which favour Federal control are implicit in the following objections to a State alternative:

(a) The finances of some States are quite insuffcient to support unaided the costs of adequate medical services.

(b) State administrations have by no means achieved the uniform level of political and social enlightenment which would guarantee effective action within reasonable time.

(c) The realization of a planned and uniform development over the whole country cannot result from separate State legislation. (The compensation laws, of which there are as many as there are States, are a product of this faith; the results are before us.)
The conclusion which we must accept is that there can be no rapid, uniform, and comprehensive dovelopment of medical services except through Federal action. It does not follow that such action should include the detailed administration at State level; indeed, such a course would be quite contrary to accepted policy. But granting in full the need for local interest and initiative, for the utilization of voluntary effort, and for a course which has the sympathy as well as the service of its doctors, one must conclude that the Federal Government is the only effective agency which can take responsibility for the curative services, and which can realize the integration with the preventive services which is the declared objective of progressive medicine.

It is unlikely that the present Congress will support such a development. On this matter, as on many others, the choice between Republican and Democrat is for the American voter the choice between the left boot and the right; the point of application is the same. He is asked to choose, not between alternative policies, but between alternative administrations of what is on essentials a common policy. Of the broad issues which roughly divided the Whig from the Jacksonian democrat of a hundred years ago, nearly all are to-day outdated (for example, slavery, free land, State currency), or are no longer points of difference between the two parties, which continue to assert no less vigorously their nominal identity.

Indeed, this was the case during the last half of the nineteenth century, of which the Beards write (1946): “. . . throughout most of the period neither of the two major political parties which contended for power and in one season or another governed the nation, took much account of the volcanic upheavals in American life and labour, or made any substantial alteration in the form, methods, or concepts of their obligations," and ". . . the two major parties were becoming as much alike in their interests and sentiments as two bottles of the same size and shape, differing only in their labels." Both have practised a form of political contraception which insures that however suggestive the preliminary movements there are no embarrassing legislative consequences. In the circumstances the fact that this political rivalry should have continued to engage the attention of the average American must be attributed to his failure to identify the problems of the day with the exercise of his vote.

It is useless to protest that politics should be kept out of medicine, and issues decided on their technical rather than on their political merits. The decision to accept or reject the Murray-Wagner-Dingell Bill, or any subsequent legislation of the same type, impinges on fundamentals of American economic 
organization, and it is not surprising that arguments heard in public are not always the most cogent. The warmth with which many speakers expressed themselves at the Senate hearings on the bill, suggests that American experience is no exception to the general rule that fundamental changes in the organization of medical services are not made without widespread political controversy, involving not only the medical profession and the politicians who represent its sectional interests. That the hearings should have called for an expression of opinion from organized labour, the American Association of Manufacturers, the Chamber of Commerce, the Farmers' Union, the National Lawyers' Guild, the League of Women Shoppers, and many other organizations which speak with less authority on medical than on political problems, suggests implications envisaged in a bill which ostensibly has no wider objective than the creation of a prepaid medical service, not essentially different from a type in operation in England for over thirty years, and in parts of Europe for considerably longer.

Perhaps the most important of these interests is the desire of the States to avoid intrusion in local affairs by the Federal Government. In part this is the result of a natural wish to decentralize authority in a country so large and with such varied problems that effective administration is inconceivable without a high degree of local autonomy. But it is also something more. The original thirteen States had united for the specific purpose of waging war against a remote central government. For some of them the signing of a Constitution which granted extended powers to a Federal authority was an act of reluctant faith, a fact which even to-day, after a hundred and sixty years and a civil war, is not forgotten. To what extent the perpetuation of this view is attributable to political expediency rather than to history is uncertain. What is certain is that whatever its cause it operates against proposals to extend Federal powers.

There is a further difficulty in the separation of the technical from the political issue. The charge that a bill to create a medical service supported by taxation or by compulsory insurance is a socialist measure to be resisted on principle, gains the support of many people who see in it the thin edge of the socialist wedge. The confusion of thought which identifies freedom of the individual with freedom to make profit is associated with a failure to realize that society must limit the latitude which it grants to individuals in the pursuit of their private ends, at the point at which it conflicts with the common interest. If only Federal action can result in an adequate distribution of medical facilities and services, there is clearly no basis for reasonable objection in the fact that it implies control. Yet many people express a dislike of " government in medicine," the medical corollary of the general thesis " the best government is no government." This is not the council of opposition, but of anarchy.

It would certainly be unwise to venture any judgment on the probable future development of American medical services, which must be influenced at least as much by economic and political imponderables as by medical needs. It is permissible, however, to consider what factors favour or prejudice such development, and to the extent that it is determined by facilities and resources rather than by the will to reconsider their more effective use, to assess the adequacy of American equipment for the complex task of providing a modern medical service.

The United States starts with the considerable advantage of having more doctors per 1,000 population than any other large country. They are, of course, very unequally distributed (Table V), but if this fault is corrected the gross overall deficiency of personnel which complicates the problem elsewhere is not present. There are, moreover, facilities for the training of professional staff which can be counted on to accommodate any reasonable extension of existing needs.

A second asset is the natural wealth of the country. The United States can afford, as can no other great nation to-day, to pay in full the heavy cost of modern services and facilities. Indeed, as the rapid passage of the Hospital Survey and Construction Act indicates, the country is very willing to provide funds, and to implement policy with an energy which no other country could surpass, where the merits of the medical case can be sharply isolated from political issues. In recent years the rapid development of Blue Cross plans has established the principle of insurance against the costs of hospitalization, and helped to destroy the notion of the hospital as a legitimate source of private profit (Table XV). The act in consequence was not considered to offend the principle of personal liberty, and had a comparatively easy passage through Congress. The same is true of the National Mental Health Act, which provides funds for research in mental health, and which became law in June, 1946.

Finally, it is always easier to follow than to create precedent. Many countries have followed the lead which Germany gave in 1883 in the introduction of compulsory health insurance, and the history of their successes and failures is available as evidence. Nowhere has this evidence been more carefully 
considered than in the United States, where technical knowledge of the administration of national health insurance is in striking contrast to the political diffidence which refuses to countenance.it.

Against these impressive assets must be set numerous difficulties already referred to, which are no less formidable because they are political in character rather than technical. The opposition of the States to Federal action; the disinclination of the medical profession to exchange a form of practice which it knows for another of which it is suspicious; the ignorance of the general public of the technical issues involved in choice between alternative methods of distributing and paying for medical care; and above all the complexity of the political machinery which may delay correction of quite conspicuous abuses: these are the realities of a complex situation. It would, moreover, be quite misleading to suggest that, since staff and facilities can be made available, only the will to use them is needed to complete a model service.

It is true, however, that the growth of American social and political institutions has not been commensurate with the rapid development of technical resources, a generalization not more true of medicine than of other fields. But it is the saving grace of American life that abuses are so quickly exaggerated that they can no longer be tolerated, and the fact that in England it has taken over thirty years to move from the first stages of compulsory health insurance to a comprehensive service should not mislead us into anticipating a comparable period for the United States.

\section{REFERENCES}

American Medical Association (1934). J. Amer. med. Ass., 102, 2199.

(1938). Ibid., 111, 59.

(1948a). Ibid., 136, 626.

(1948b). News Letter, 5, 1.

American Public Health Association (1940a). Year Book 1940-41, p. 49.

(1940b). Ibid., p. 46.

Bachmeyer (1947). J. Amer. med. Ass., 133, 1050 (discussion).

Beard, C., and Beard, M. (1946). " The Basic History of the United States," pp. 322, 328. Doubleday and Co. Inc., New York.

Bureau of Medical Economics (1933). J. Amer. med. Ass., 100, 1605, 1693, 1773.

(1941). Ibid., 117, 122.

Clark, D. A., and Clark, K. G. (1941). Organization and Administration of Group Medical Practice. Joint Committee of the Twentieth Century and the Good Will Fund, and Medical Administration Service Inc., Boston.
Clark, K. C., Hart, P. D., Kerley, P., and Thompson, B. C. (1945). Spec. Rep. Ser. med. Res. Coun., Lond., Number 251. H.M.S.O.

Committee on the Costs of Medical Care (1932). Final Report of the Committee on the Costs of Medical os Care. Publication Number 28, University of Chicago Press, Chicago.

Corwin, E. H. L. (1946). "The American Hospital." 107, The Commonwealth Fund, New York.

Dickinson, F. G. (1948). J. Amer. med. Ass., 136, 333.

Falk, I. S., Klem, M. C., and Sinai, N. (1933). Committee on the Costs of Medical Care. Publication $\vec{D}$ Number 26, University of Chicago Press, Chicago.

Garfield, S. R. (1944). J. Amer. med. Ass., 126, 337.

Goldmann, F. (1941). Medical Care, 1, 301.

- (1946). Connecticut Med. J., 10, 289.

Hoge, V. M. (1947). Publ. Hlth Rep., Wash., 62, 49.

Hospital Survey and Construction Act (1946).

General Regulations (1947). J. Amer. med. Ass., 133, 946.

Hunt, G. H. (1947). New Engl. J. Med., 237, 71.

-, and Goldstein, M. (1947a). Ibid., 237, 719. (1947b). J. Amer. med. Ass., 135, 904.

Lueth, H. C. (1945). Ibid., 128, 528.

Moore, J. E. (1943). Hospitals, 17, 47.

Mountin, J. W., and Flook, E. (1941). Publ. Hlth Rep., Wash., 56, 1676.

Mustard, H. S. (1945a). "Government in Publicō Health." p. 20, The Commonwealth Fund, Newo York.

(1945b). Ibid., p. 101.

(1945c). . Ibid., p. 137.

(1945d). Ibid., p. 189.

National Health Act (1947). S.545.

National Health Survey 1935-36 (1945). “" Illness and Medical Care among 2,500,000 persons in 83 cities? with special reference to Socio-Economic Factors."으 United States Government Printing Office, Wash 3 . ington.

National Insurance and Public Health Act (1947) S.1320.

National Mental Health Act (1946).

Parran, T. (1946). Testimony of the Surgeon General, U.S.P.H.S., before the Public Health Subcommittee of the House Committee on Interstate and Foreignor Commerce, March 7.

$$
\text { (1947). J. Amer. med. Ass., 133, } 1047 .
$$$$
\text { (1948), J.A. Am. M. Coll., 23, } 18 .
$$

Report of the Committee on Medical Preparedness (1942.)

Rorem, C. R. (1931). Washington Committee on the Costs of Medical Care, Publication Number 8.

(1945). The Voluntary Hospital looks ahead $\stackrel{0}{\mathbb{D}}$ Report of Proceedings, Third Wartime Symposium United States Hospital Fund, New York.

Ryan, E. E. (1947). Medical Economics, 25, 128. 
Scott, M. (1947). Ibid., 26, 65.

Sinai, N., Anderson, O. W., and Dollar, M. L. (1946a). Health Insurance in the United States. p. 48, Commonwealth Fund, New York. (1946b). Ibid., p. 58.

Stern, B. J. (1945a). American Medical Practice in the Perspective of a Century, p. 49, Commonwealth Fund, New York.
Stern, B. J. (1945b). Ibid., p. 50.

(1946a). Medical Services by Government, Local, State, and Federal, p. 145, Commonwealth Fund, New York.

(1946b). Ibid., p. 175.

Sydenstricker, E. (1926). Public Health Reports (Reprint 1133) and ten other papers in the Public Health Reprints 1926-29. 